This document is confidential and is proprietary to the American Chemical Society and its authors. Do not copy or disclose without written permission. If you have received this item in error, notify the sender and delete all copies.

\title{
Tsv (Tosvinyl) and Bsv (Besvinyl) as Protecting Groups of Imides, Azinones, Nucleosides, Sultams, and Lactams. Catalytic Conjugate Additions to Tosylacetylene
}

\begin{tabular}{|r|l|}
\hline Journal: & The Journal of Organic Chemistry \\
\hline Manuscript ID: & jo-2014-01647w.R1 \\
\hline Manuscript Type: & Article \\
\hline Date Submitted by the Author: & 19-Aug-2014 \\
\hline Complete List of Authors: & $\begin{array}{l}\text { Petit, Elena; Universitat de Barcelona, Departament de Química Orgànica } \\
\text { Bosch, Lluís; Universitat de Barcelona, Departament de Química Orgànica } \\
\text { Font, Joan; Universitat de Barcelona, Departament de Química Orgànica } \\
\text { Mola, Laura; Universitat de Barcelona, Departament de Química Orgànica } \\
\text { Costa, Anna; Universitat de Barcelona, Departament de Quimica Organica } \\
\text { Vilarrasa, Jaume; Universitat de Barcelona, Departament de Química } \\
\text { Orgànica }\end{array}$ \\
\hline
\end{tabular}




\title{
Tsv (Tosvinyl) and Bsv (Besvinyl) as Protecting Groups of Imides,
} Azinones, Nucleosides, Sultams, and Lactams. Catalytic Conjugate Additions to Tosylacetylene

\author{
Elena Petit, Lluís Bosch, Joan Font, Laura Mola, Anna M. Costa,* and Jaume Vilarrasa* \\ Departament de Química Orgànica, Facultat de Química, Universitat de Barcelona, Diagonal 645, 08028 Barcelona, Catalonia, Spain \\ amcosta@ub.edu, jvilarrasa@ub.edu
}

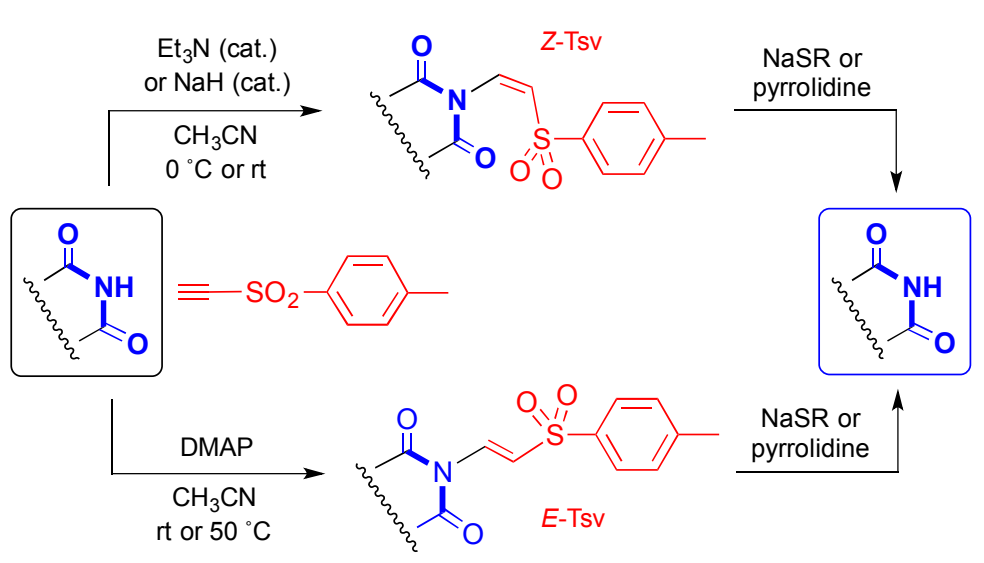

\begin{abstract}
The use of the 2-(4-methylphenylsulfonyl)ethenyl (Tosvinyl, Tsv) group for the protection of the NH group of a series of imides, azinones (including AZT), inosines, and cyclic sulfonamides has been examined. The Tsv-protected derivatives are obtained in excellent yields by conjugate addition to tosylacetylene (ethynyl $p$-tolyl sulfone). The stereochemistry of the double bond can be controlled at will: with only $1 \mathrm{~mol} \%$ of $\mathrm{Et}_{3} \mathrm{~N}$ or with catalytic amounts of $\mathrm{NaH}$ the $Z$ stereoisomers are generated almost exclusively, while the $E$ isomers are obtained using a stoichiometric amount of DMAP. Analogous phenylsulfonylvinyl-protected groups (with the Besvinyl or Bsv group instead of Tsv) are obtained stereospecifically by reaction with $(Z)$ - or $(E)$-bis(phenylsulfonyl)ethene. For lactams and oxazolidinones, this last method is much better. The Tsv and Bsv groups are stable in the presence of non-nucleophilic bases and to acids. They can be removed highly effectively via a conjugate addition-elimination mechanism using pyrrolidine or sodium dodecanethiolate as nucleophiles.
\end{abstract}

\section{INTRODUCTION}

Due to the strong electron-withdrawing character of the sulfonyl group, 1-alkynyl and 1-alkenyl sulfones can participate as acceptors in Michael-type additions and in [4+2]-, [3+2]-, and [2+2]-cycloadditions. Consequently, they have many synthetic applications. ${ }^{1}$ We were interested in the conjugate additions of nucleophiles to ethynyl sulfones, in comparison with those to other electron-deficient triple bonds. ${ }^{2}$ In this regard, we planned to take advantage of the reactivity of commercially available 1- 
(ethynylsulfonyl)-4-methylbenzene (ethynyl $p$-tolyl sulfone, $\mathrm{Ts}-\mathrm{C} \equiv \mathrm{CH}$ ), commonly called tosylacetylene, to develop a procedure for the protection of heterocyclic compounds with activated $\mathrm{NH}$ groups. As shown in Scheme 1, this would require a conjugate addition (aza-Michael addition) under very mild conditions to afford quickly, quantitatively, and selectively either $Z$-vinyl or E-vinyl sulfone derivatives as desired. The stability of these 2-(4-tolylsulfonyl)ethenyl groups (2-tosylvinyl, Tosvinyl, Tsv), ${ }^{3}$ and appropriate conditions for their removal should be then evaluated.

Scheme 1. Tosylacetylene as a Reagent for the

Protection of CONHCO and Related Groups
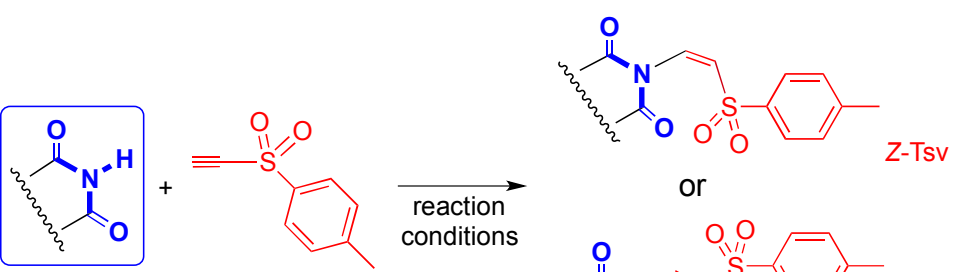

or

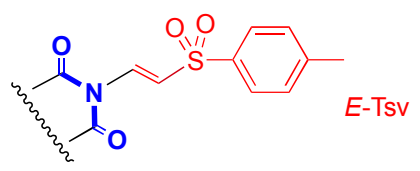

The reaction of tosylacetylene with thiols was examined exhaustively by the research group of Plumet and Arjona, ${ }^{4}$ with whom some of us collaborated to develop a chemoselective protection scheme for thiol groups. ${ }^{4 \mathrm{~b}, 5} \mathrm{O}$-Nucleophiles and amines also react with tosylacetylene, ${ }^{1 \mathrm{c}}$ and there are also a few examples of the addition of the CONH groups of heterocyclic compounds to alkynyl sulfones. ${ }^{6}$ However, despite the scarcity of good methods for the protection of these moieties, ${ }^{3}$ and even though it is a functionality that very often requires protection during the synthesis of drugs, the use of the Tsv group has not been studied in detail. ${ }^{6 b, 7}$ In this connection, we have comparatively evaluated, for the first time, the protection with Tsv of several relatively acidic NH groups (see Figure 1): carboximides $\mathbf{1 a}$ and $\mathbf{1} \mathbf{b}$; the special imide moiety of a pyrimidine nucleoside $(O$-Ac-AZT, 1c); the particular amide groups of 2-pyridone (1d), 2-hydroxyquinazoline (quinazolone 1e), and inosine 1f; cyclic sulfonamides (sultams $\mathbf{1 g}$ and $\mathbf{1 h}$ ); and an $\mathrm{N}$-acylsultam (saccharin, 1i). Less acidic NH-containing substrates such as lactams $\mathbf{1} \mathbf{j}$ and $\mathbf{1 k}$ and a cyclic carbamate (oxazolidinone 11, Figure 1) were also included in the set. It was crucial that Tsv could be introduced with $Z$ or $E$ configuration as desired, to avoid the formation of mixtures of stereoisomers that would complicate the characterization of the protected products. In several cases, the preparation of derivatives with a 2(benzenesulfonyl)ethenyl or 2-besylvinyl substructure $\left(\mathrm{PhSO}_{2} \mathrm{CH}=\mathrm{CH}\right.$, Besvinyl, Bsv) was also studied for the sake of comparison. We believe that this study expands the scope of the use of Tsv and related groups in organic synthesis, which is currently somewhat limited. 
1

2

3

4

5

6

7

8

9

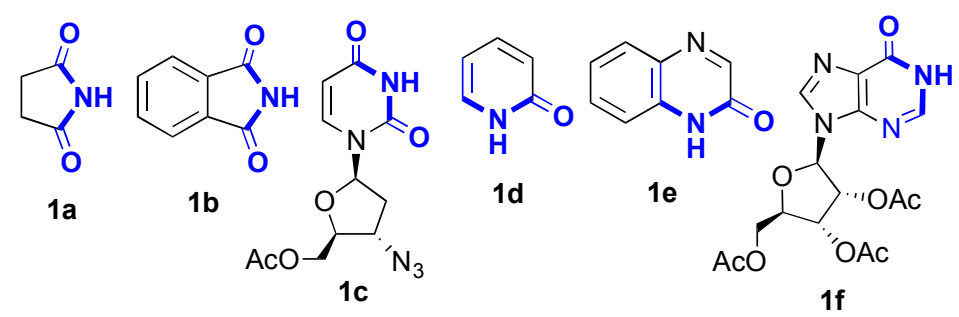

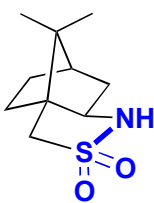

$1 \mathrm{~g}$

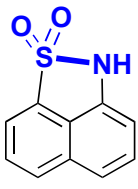

1h

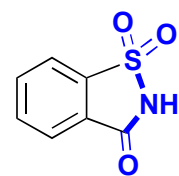

1i

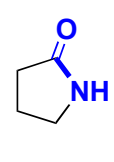

1j

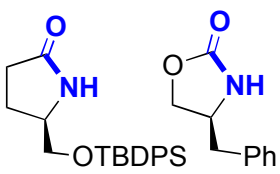

$1 \mathrm{k}$

Figure 1. Set of compounds studied.

\section{RESULTS AND DISCUSSION}

The great reactivity of electron-deficient triple bonds, linked to strong EWGs such as $\mathrm{SO}_{2} \mathrm{Ar}$, with nucleophiles should facilitate the attachment of Tsv to the nitrogen of amides and imides, which are poorly nucleophilic unless they are converted into their more reactive anions. Several bases and catalysts are reported for similar reactions. ${ }^{2,4,6}$ To identify the best conditions for the stereoselective introduction of Tsv, we started by studying the reaction of succinimide (1a), with a relatively acidic $\mathrm{NH}$ group, with tosylacetylene, promoted by $\mathrm{Et}_{3} \mathrm{~N}$, DIPEA (a basic but poorly nucleophilic tertiary amine), NaH, DMAP, and DABCO (the last two less basic than a standard tertiary amine but highly nucleophilic). The results of this preliminary screening are shown in Table 1.

Succinimide, 1a, does not react with tosylacetylene alone at rt (entry 1), as expected, but the reaction is strongly accelerated by the presence of a small amount of a base. All the basic catalysts tested afford complete conversion in less than 30 min, even at $0{ }^{\circ} \mathrm{C}$ and with only a trace of the base. The $Z$ stereoisomer $\mathbf{2 a}$ is always the major product, although the degree of selectivity changes depending on the base and conditions. The results obtained using $\mathrm{Et}_{3} \mathrm{~N}$ or DIPEA are similar although the reactions with the latter (compare entry 5 to 2 ) are slightly more $Z$-selective. In order to obtain $\mathbf{2 a}$ exclusively, with $\mathrm{Et}_{3} \mathrm{~N}$, it is necessary to work with only a trace of the base at $0{ }^{\circ} \mathrm{C}$ (entry 4). Catalytic amounts of $\mathrm{NaH}$ (entries 8 and 9) also afford 2a with complete stereoselectivity, instantaneously. Finally, we examined two bases of well-known nucleophilicity, DMAP and DABCO, ${ }^{8}$ which gave mixtures of stereoisomers (entries 10-12 and 14). However, on prolonged heating with DMAP or DABCO the more stable $E$ isomer (3a) became the major compound (entries 13 and 15); the yields obtained with DABCO were slightly lower than with DMAP. ${ }^{9}$ Heating in the presence of $\mathrm{Et}_{3} \mathrm{~N}$ caused a much slower isomerization. Thus, it appears that adducts generated under kinetic control (basic medium) $)^{5}$ isomerize to the thermodynamically favored $E$ isomers in the presence of the more nucleophilic bases (slowly at rt, quantitatively after prolonged heating). 
Table 1. Screening of the reaction conditions for the addition of succinimide (1a) to tosylacetylene ${ }^{a}$

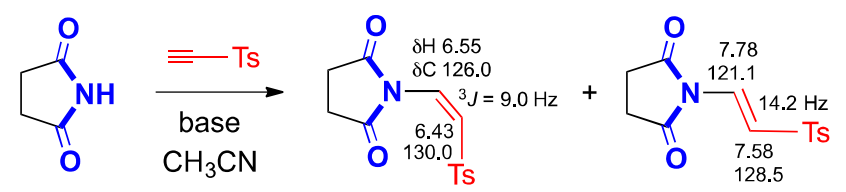

$1 \mathbf{a}$

$2 \mathbf{a}$

$3 \mathbf{a}$

\begin{tabular}{c|l|ccc|c|c|} 
entry & $\begin{array}{l}\text { base or catalyst } \\
\text { (equiv) }\end{array}$ & $\begin{array}{c}T \\
\left({ }^{\circ} \mathrm{C}\right)\end{array}$ & $\begin{array}{c}\text { time } \\
(\mathrm{h})\end{array}$ & $\begin{array}{c}\text { conv. } \\
(\%)\end{array}$ & $\begin{array}{c}\text { yield } \\
(\%)\end{array}$ & $\begin{array}{c}\mathbf{2 a} / \mathbf{3 a} \\
(Z / E)^{b}\end{array}$ \\
\hline 1 & & 20 & 24 & 0 &
\end{tabular}

$\begin{array}{lllllll}2 & \mathrm{Et}_{3} \mathrm{~N}(0.1) & 20 & 0.2 & 100 & 87 & 86: 14\end{array}$

$3 \quad \mathrm{Et}_{3} \mathrm{~N}(0.1) \quad 00.2 \quad 100 \quad 91 \quad 88: 12$

$\begin{array}{lllllll}4 & \operatorname{Et}_{3} \mathrm{~N}(0.01) & 0 & 0.2 & 100 & 92 & >99: 1^{c}\end{array}$

$\begin{array}{lllllll}5 & \text { DIPEA (0.1) } & 20 & 0.2 & 100 & 95 & >99: 1^{c}\end{array}$

$6 \quad$ DIPEA $(0.05) \quad 20 \quad 0.2 \quad 100 \quad 94 \quad>99: 1^{c}$

$\begin{array}{lllllll}7 & \text { DIPEA (0.01) } & 0 & 0.3 & 100 & 92 & >99: 1^{c}\end{array}$

$\begin{array}{lllllll}8 & \mathrm{NaH}(0.2) & 20 & <0.2 & 100 & 97 & >99: 1^{c}\end{array}$

$\begin{array}{lllllll}9 & \text { NaH (0.05) } & 20 & <0.2 & 100 & 97 & >99: 1^{c}\end{array}$

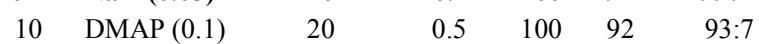

$\begin{array}{lllllll}11 & \text { DMAP (0.5) } & 20 & 0.2 & 100 & 92 & 74: 26\end{array}$

$\begin{array}{lllllll}12 & \text { DMAP (1.0) } & 20 & 0.2 & 100 & 90 & 55: 45\end{array}$

$\begin{array}{lllllll}13 & \text { DMAP (1.0) } & 50 & 48 & 100 & 90 & <1: 99^{c}\end{array}$

$\begin{array}{lllllll}14 & \mathrm{DABCO}(0.2) & 20 & 0.2 & 100 & 88 & 70: 30\end{array}$

$\begin{array}{lllllll}15 & \text { DABCO (1.0) } & 50 & 48 & 100 & 84 & <1: 99^{c}\end{array}$

a Standard conditions: 1a and tosylacetylene (1.2 equiv) were dissolved in $\mathrm{CH}_{3} \mathrm{CN}(0.1 \mathrm{M})$ under $\mathrm{N}_{2}$ and the base was added at $0{ }^{\circ} \mathrm{C}$; stirring was maintained at the temperature shown above, for the time indicated; the isolated yields of isomers $E+Z$ are given. ${ }^{b} E / Z$ ratios were determined by ${ }^{1} \mathrm{H}$ NMR $(400 \mathrm{MHz}) .{ }^{c}$ The minor isomer was not detected by ${ }^{1} \mathrm{H}$ NMR $(400 \mathrm{MHz})$.

The NMR signals of the products proved to be diagnostic. This is an advantage of this kind of PG (with a double bond), as the introduction and removal can be easily followed by NMR spectroscopy. For the sake of comparison we allowed 1a to react with (Z)-1,2-bis(phenylsulfonyl)ethene and with (E)-1,2-bis(phenylsulfonyl)ethene, both commercially available. ${ }^{10}$ As summarized in Scheme 2, adduct $Z$ (4a) was formed with the former reagent and adduct $E$ (5a) with the latter, with an excellent stereospecificity. ${ }^{10}$ By analogy to the Tsv group, ${ }^{3}$ we call these 2-(phenylsulfonyl)ethenyl substituents $(Z)$ - and $(E)$-Besvinyl groups, or simply Z-Bsv and E-Bsv, as they contain benzenesulfonylvinyl moieties. The NMR spectra of $\mathbf{4 a}$ and $\mathbf{5 a}$ correlated perfectly with those of $\mathbf{2} \mathbf{a}$ and $\mathbf{3 a}$, respectively, as anticipated. ${ }^{11}$ 
1

2

3

4

5

6

7

8

9

10

\section{Scheme 2. Reaction of 1a with 1,2-Bis(sulfonyl)ethenes}

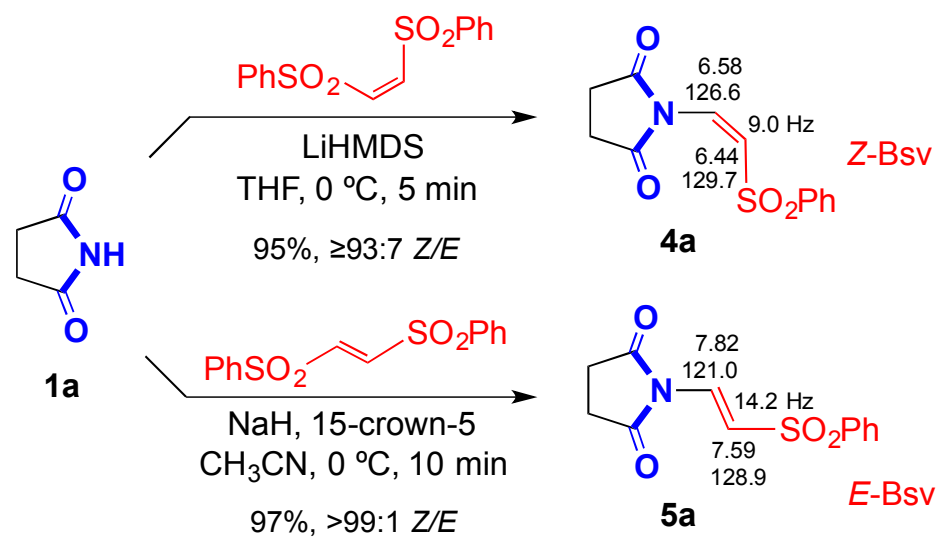

Having established suitable conditions for the selective preparation of either the $Z$ - or $E$-protected succinimides, we extended the study to other compounds containing similar, relatively acidic NH, such as compounds $\mathbf{1 b}-\mathbf{1 i}$ shown in Figure 1 .

The results obtained in the preparation of $Z$ derivatives, $\mathbf{2}$, are shown in Table 2 . In all cases, the yields were excellent. Experiments carried out in 1:1 $\mathrm{CH}_{2} \mathrm{Cl}_{2} / \mathrm{CH}_{3} \mathrm{CN}$ or in THF, although not included in Table 2 for the sake of simplicity, gave similar or only slightly lower results, respectively. The $E$ isomers were rarely detected; they were only noted in the cases of pyridone (1d), inosine (1f), and naphthosultam (1h), but as very minor products. Saccharin (1i), with a highly acidic NH (p $K_{\mathrm{a}}$ $=1.6$ in $\mathrm{H}_{2} \mathrm{O},{ }^{12 \mathrm{a}} \mathrm{p} K_{\mathrm{a}}=4$ in $\mathrm{DMSO}^{12 \mathrm{~b}}$ ), with a poorly nucleophilic anion, reacts very slowly, even in the presence of stoichiometric amounts of DIPEA or $\mathrm{Et}_{3} \mathrm{~N}$; however, Z-Tsv-protected saccharin $2 \mathbf{i}$ can be prepared by using NaH (entry 10 ). It is uncommon for an $\mathrm{N}$-acylsulfonamide moiety embedded in a drug to require protection, but we included this compound in the set to check the capacity of "sodium saccharine" to behave as a nucleophile against triple bonds activated by an electronwithdrawing group. ${ }^{13}$ 
Table 2. Preparation of $Z$-Tsv-protected compounds $2 \mathrm{~b}-2 \mathrm{i}^{a}$
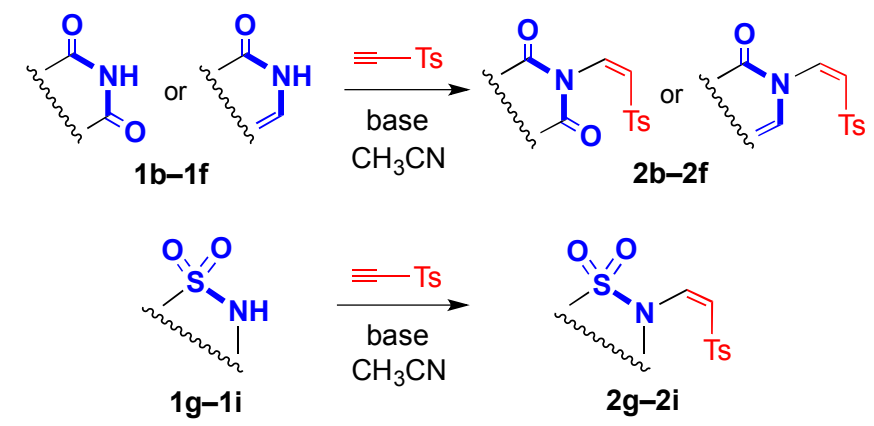

$\begin{array}{lclcccc}\text { entry } & \text { substrate } & \text { base (equiv) } & T\left({ }^{\circ} \mathrm{C}\right) & \text { time }(\mathrm{h}) & \text { yield }(\%) & \mathbf{2 / 3}(Z / E)^{b} \\ 1 & \mathbf{1 b} & \mathrm{Et}_{3} \mathrm{~N}(0.01) & 0 & 0.2 & 89 & >99: 1^{c} \\ 2 & \mathbf{1 c} & \mathrm{Et}_{3} \mathrm{~N}(0.03) & 0 & 0.3 & 85 & >99: 1^{c} \\ 3 & \mathbf{1 d} & \mathrm{Et}_{3} \mathrm{~N}(0.01) & 0 & 0.6 & 92 & 98: 2 \\ 4 & \mathbf{1 d} & \mathrm{DIPEA}(0.01) & 0 & 1.0 & 89 & 93: 7^{c} \\ 5 & \mathbf{1 e} & \mathrm{Et}_{3} \mathrm{~N}(0.01) & 20 & 0.1 & 92 & >99: 1^{c} \\ 6 & \mathbf{1 e} & \mathrm{NaH}^{c}(0.2) & 20 & 0.5 & 87 & >99: 1^{c} \\ 7 & \mathbf{1 f} & \mathrm{Et}_{3} \mathrm{~N}(0.03) & 10 & 0.5 & 86 & 95: 5 \\ 8 & \mathbf{1 g} & \mathrm{Et}_{3} \mathrm{~N}(0.03) & -5 & 1.0 & 87 & >99: 1^{c} \\ 9 & \mathbf{1 h} & \mathrm{Et}_{3} \mathrm{~N}(0.03) & 20 & 2.5 & 96 & 98: 2^{c} \\ 10 & \mathbf{1 i} & \mathrm{NaH}^{c}(0.2) & 20 & 1.6 & 90^{e} & >99: 1^{c}\end{array}$

${ }^{a}$ Standard conditions: 1b-1i and tosylacetylene (1.2 equiv) were dissolved in $\mathrm{CH}_{3} \mathrm{CN}(0.1 \mathrm{M})$ under $\mathrm{N}_{2}$ and the corresponding base was slowly added at $0{ }^{\circ} \mathrm{C}$. Stirring at the temperature shown in the Table was maintained for the time indicated. The isolated yields of isomers $E+Z$ are given. ${ }^{b} E / Z$ ratios were determined by ${ }^{1} \mathrm{H}$ NMR. ${ }^{c}$ The minor isomer was not detected by ${ }^{1} \mathrm{H}$ NMR. ${ }^{d} \mathrm{CH}_{3} \mathrm{CN} / \mathrm{CH}_{2} \mathrm{Cl}_{2}$ (1:1) was used as the solvent. ${ }^{e}$ Conversion was complete, but the product partially decomposed when purification was attempted by column chromatography.

Isomerization of $Z$ isomers, once isolated, to $E$ isomers could be accomplished by nucleophilic catalysis. For example, isomerization of $(Z)-\mathbf{2 b}$ to $(E)$-3b was complete by addition of a stoichiometric amount of DMAP and heating at $50{ }^{\circ} \mathrm{C}$ for $48 \mathrm{~h}$. With substoichiometric amounts of DMAP or DABCO the isomerization was incomplete. ${ }^{14}$

We could obtain directly the $E$ stereoisomers as indicated in the case of 1a, that is, by reaction of the substrate with 100 mol $\%$ of DMAP for many hours (Table 3). In fact, to achieve complete formation of the $E$ isomer, heating was necessary in most of the cases, but not always (entries 3 and 5). With one equiv of DABCO instead of one equiv of DMAP, the yields of $\mathbf{3}$ were lower (in the $60-88 \%$ range, data not shown in Table 3 ). ${ }^{9}$ 
Table 3. Preparation of $E$-Tsv-protected compounds $3 b-3 h^{a}$

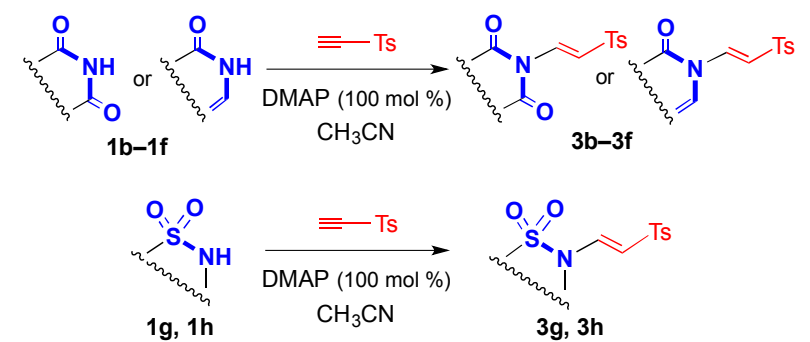

\begin{tabular}{ccccccc} 
entry & substrate & base & $T\left({ }^{\circ} \mathrm{C}\right)$ & time (h) & yield $(\%)$ & $\mathbf{3}, E / Z^{b}$ \\
\hline 1 & $\mathbf{1 b}$ & DMAP & 50 & 48 & 98 & $\mathbf{3 b},>99: 1$ \\
2 & $\mathbf{1 c}$ & DMAP & 50 & 48 & 80 & $\mathbf{3 c},>99: 1$ \\
3 & $\mathbf{1 d}$ & DMAP & 20 & 24 & 96 & $\mathbf{3 d},>99: 1$ \\
4 & $\mathbf{1 e}$ & DMAP & 50 & 48 & 84 & $\mathbf{3 e},>99: 1$ \\
5 & $\mathbf{1 f}$ & DMAP & 20 & 48 & 90 & $\mathbf{3 f},>99: 1$ \\
6 & $\mathbf{1 g}$ & DMAP & 50 & 48 & 82 & $\mathbf{3 g},>99: 1$ \\
7 & $\mathbf{1 h}$ & DMAP & 50 & 48 & 97 & $\mathbf{3 h},>99: 1$
\end{tabular}

${ }^{a}$ Standard conditions: $\mathbf{1} \mathbf{a}-\mathbf{1} \mathbf{h}$ and and tosylacetylene (1.2 equiv) were dissolved in $\mathrm{CH}_{3} \mathrm{CN}(0.1 \mathrm{M})$ under $\mathrm{N}_{2}$ and DMAP (1.0 equiv) was then added. Stirring at the temperatures shown in the Table was maintained for the time indicated. ${ }^{b} E / Z$ ratios determined by ${ }^{1} \mathrm{H}$ NMR. ${ }^{c} \mathrm{CH}_{3} \mathrm{CN} / \mathrm{CH}_{2} \mathrm{Cl}_{2}(1: 1)$ was used as the solvent.

Again, the behavior of saccharin was special. Mixing equivalent amounts of saccharin (1i) and DMAP in $\mathrm{CH}_{3} \mathrm{CN}$ caused immediate precipitation of the 4-(dimethylamino)pyridinium salt of saccharin, which dissolved as soon as tosylacetylene was added. After a few minutes another salt precipitated, which was identified as $6 .{ }^{15}$ This probably results from conjugate addition of DMAP to tosylacetylene followed by protonation of the resulting anion by saccharin (Scheme 3). The isolation of this salt is consistent with the role of DMAP as a nucleophilic catalyst or promoter. Compound $\mathbf{6}$ remained unaltered when heated in $\mathrm{CH}_{3} \mathrm{CN}$ for one day. Nevertheless, $\mathbf{3 i}$ was isolated in $90 \%$ yield by treatment of its $Z$ stereoisomer, $\mathbf{2} \mathbf{i}$, prepared as reported in Table 2, with a catalytic amount of DMAP at rt.

Scheme 3. Formation of Salt 6 and Isomerization of $2 \mathrm{i}$ to $3 \mathrm{i}$
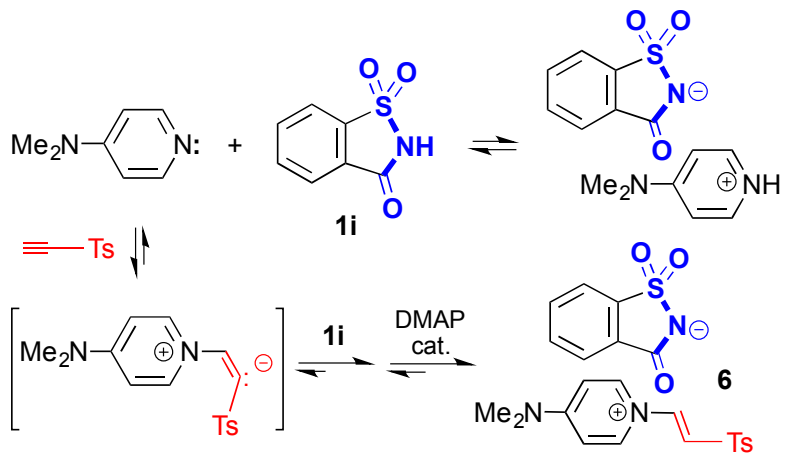<smiles>O=C1c2ccccc2S(=O)(=O)N1C=C[13I]</smiles>

2i

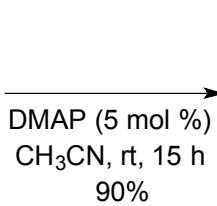

$90 \%$

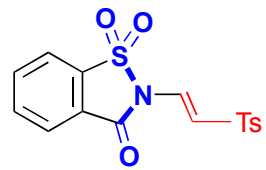

$3 \mathbf{i}$ 
The less acidic lactams $\mathbf{1} \mathbf{j}$ and $\mathbf{1} \mathbf{k}$ and oxazolidinone $\mathbf{1 l}$ do not react with $\mathrm{H}-\mathrm{C} \equiv \mathrm{C}-\mathrm{Ts}$ under the conditions optimized for the Z-Tsv and $E$-Tsv derivatives. ${ }^{16}$ As an alternative, we could examine their synthetic equivalents $\mathrm{X}-\mathrm{CH}=\mathrm{CH}-\mathrm{SO}_{2} \mathrm{Ar}(\mathrm{X}=$ halogen or other good leaving groups). ${ }^{17}$ In practice, we have used 1,2-bis(phenylsulfonyl)ethenes $\left(\mathrm{PhSO}_{2}-\mathrm{CH}=\mathrm{CH}-\mathrm{SO}_{2} \mathrm{Ph}\right)$ for the protection of $\mathbf{1} \mathbf{j}-$ 11 (as Bsv derivatives, see Scheme 2), by means of the known stereospecific Ad-E reaction ${ }^{66,7,10}$ of nucleophiles to these activated alkenes. Our results are summarized in Scheme 4. Thus, by reaction with (Z)-1,2-bis(phenylsulfonyl)ethene, the lithium salts of $\mathbf{1 j}-\mathbf{1 l}$ afforded Z-Bsv-protected compounds $\mathbf{4 j - 4 l}$ with high selectivity, whereas with the sodium salts (generated from NaH or NaHMDS, either in sub-stoichiometric or stoichiometric amounts) we obtained a mixture of Z-Bsv and $E$-Bsv derivatives. On the other hand, by reaction with $(E)$-1,2-bis(phenylsulfonyl)ethene, the sodium salts of $\mathbf{1} \mathbf{j}-\mathbf{1 1}$, in the presence of an excess of 15 -crown-5, gave exclusively the desired $E$-Bsv derivatives.

\section{Scheme 4. Preparation of $4 j-4 l$ and $5 j-5 l$}

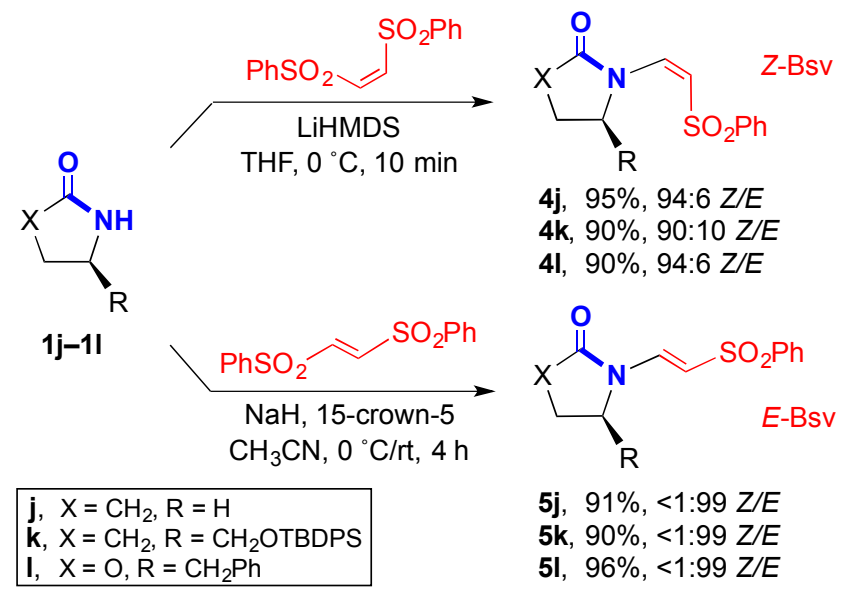

The stabilities of the $\mathrm{CON}-\mathrm{Tsv}, \mathrm{CON}-\mathrm{Bsv}, \mathrm{SO}_{2} \mathrm{~N}-\mathrm{Tsv}$, and $\mathrm{SO}_{2} \mathrm{~N}-\mathrm{Bsv}$ bonds were examined in basic and acidic media. (1) Removal of the TBDPS group of $\mathbf{4 k}$ was accomplished with TBAF at $\mathrm{rt}$ in excellent yield with partial $Z$ to $E$ isomerization of the Bsv group; meanwhile, use of TBAF buffered with HOAc cleaved the silyl ether while hardly affecting the Tsv group (no isomerization). (2) Compound $\mathbf{5 k}$ could be $\alpha$-benzylated in good yield (LiHMDS, THF, $-78^{\circ} \mathrm{C}$, benzyl bromide, rt), the Bsv group remaining intact. (3) The acetyl group of $\mathbf{2 c}$ could be removed quantitatively by treatment with $1 \% \mathrm{NaOMe}$ in $\mathrm{MeOH}$, while the $Z$ configuration of the Tsv group was maintained; however, these reaction conditions could not be applied to $\mathbf{2 f}$, which suffered secondary reactions. (4) When treated with $10 \% \mathrm{TsOH} \cdot \mathrm{H}_{2} \mathrm{O}$ in $\mathrm{MeOH}$ at $\mathrm{rt}$, the acetyl groups of inosine $\mathbf{3 f}$ were slowly cleaved but the Tsv group remained unaltered; also, compounds $\mathbf{2 b}, \mathbf{2 g}$ and $\mathbf{5 l}$ were recovered intact after treatment with these reagents even on heating at $55^{\circ} \mathrm{C}$ for $48 \mathrm{~h}$. From these experiments we can conclude that the Tsv group is not sensitive to acid media or to non-nucleophilic bases. 
Several deprotection procedures, based on an addition-elimination mechanism, were examined. A selection of the most relevant results is shown in Table 4. The most general method was the use of dodecanethiol and an excess of sodium hydride (Method A). The deprotected compounds were isolated in excellent yields, as well as coproducts $\mathrm{CH}_{3}\left(\mathrm{CH}_{2}\right)_{11} \mathrm{SCH}=\mathrm{CHTs}$ or $\mathrm{CH}_{3}\left(\mathrm{CH}_{2}\right)_{11} \mathrm{SCH}=\mathrm{CHBs}$ (only isomers $E,{ }^{3} J_{\mathrm{HH}}=14.6 \mathrm{~Hz}$ ). The excess of $\mathrm{NaH}$ (relative to the thiol) was necessary, otherwise the initial intermediates from conjugate addition of the nucleophile $(N, S \text {-acetals, thiohemiaminals })^{18}$ predominated. Nevertheless, sodium dodecanethiolate alone, without additional NaH (Method B), was enough in some cases (Table 4, entries 17 and 24). Lactams $\mathbf{4 j}$ and $\mathbf{4} \mathbf{k}$ and oxazolidinone $\mathbf{4 l}$ isomerized to the corresponding $E$ isomers $\mathbf{5 j} \mathbf{j} \mathbf{5} \mathbf{l}$, and did not react further when treated with sodium dodecanethiolate (by Method A or B); this result was not unexpected bearing in mind that the dodecanethiolate ion might be a better leaving group than the anions of $\mathbf{1 j} \mathbf{- 1 1}$.

We also explored the performance of pyrrolidine (Method C) in this transformation, with satisfactory results, except for some particular cases, viz., we noted that pyrrolidine attacked the carbonyl carbon of Tsv-protected imides $\mathbf{2 a}, \mathbf{2} \mathbf{b}, \mathbf{3 a}$, 3b, and $\mathbf{3} \mathbf{f}$ rather than undergoing the desired conjugate addition. The deprotection of camphorsultam derivatives $\mathbf{2} \mathbf{g}$ and $\mathbf{3 g}$ was very slow, due to steric hindrance, but camphorsultam could be isolated in good yield by increasing the amount of pyrrolidine and the temperature (see entries 20 and 21). Lactams $\mathbf{4 j}, \mathbf{4 k}, \mathbf{5 j}$, and $\mathbf{5 k}$ could be deprotected in good yields by the combined use of pyrrolidine (4.0 equiv) and $\mathrm{NaH}$ ( 0.3 equiv) (Method $\mathrm{D}$, entries 27-30); in all other cases stable aminal intermediates predominated and could be isolated. ${ }^{19}$ Geometrical isomers $\mathbf{4} \mathbf{l}$ and $\mathbf{5 l}$ show a remarkable difference in reactivity when treated with pyrrolidine (entries 31 and 32). Whereas $\mathbf{4 l}$ ( $Z$ isomer) reacted smoothly at $\mathrm{rt}$ and furnished $\mathbf{1} \mathbf{l}$ in excellent yield, its $E$ isomer $\mathbf{5 l}$ did not react. Only after heating the reaction mixture to $55{ }^{\circ} \mathrm{C}$ did we achieve complete conversion of $\mathbf{5 l}$ to $1 \mathbf{1}$. In general, we observed that $Z$-Tsv and $Z$-Bsv were removed more readily than their thermodynamically more stable $E$ isomers, as was to be expected.

The $N$-Tsv- and $N$-Bsv-protected compounds may be transformed to the corresponding $N$-vinyl derivatives, via cleavage of the $\mathrm{C}-\mathrm{SO}_{2}$ bonds under reductive conditions. ${ }^{20}$ Also, the Tsv- and Bsv-containing compounds can be hydrogenated $\left(\mathrm{H}_{2}\right.$ balloon, $\mathrm{Pd} / \mathrm{C}$ ) within minutes to give quantitatively the corresponding 2-tosylethyl (Tosethyl, Tse ${ }^{6 \mathrm{~b}}$ ) and 2-(benzenesulfonyl)ethyl (Besethyl, Bse) derivatives, as we checked with compounds $\mathbf{3 a}, \mathbf{3 e}$, and $\mathbf{5 l}$. 
Table 4. Removal of the Tsv and Bsv groups with Nucleophiles

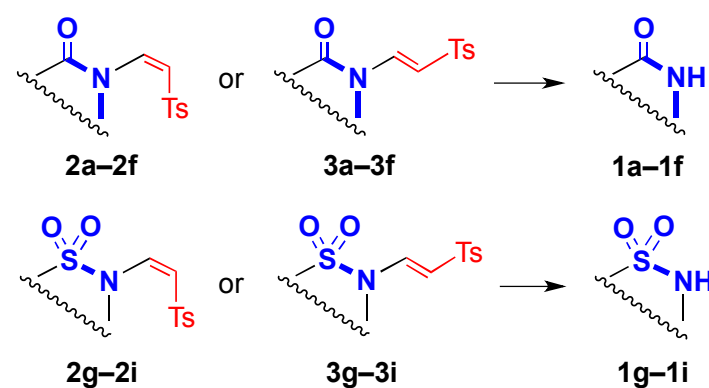

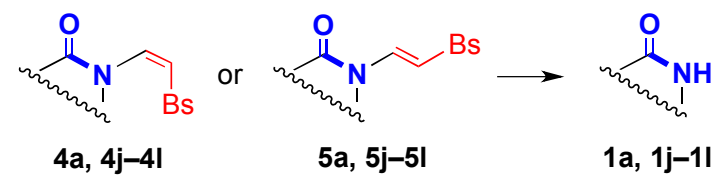

\begin{tabular}{|c|c|c|c|c|c|}
\hline entry & substrate & method $^{a}$ & $T\left({ }^{\circ} \mathrm{C}\right)$ & time (h) & $\begin{array}{c}1 \mathbf{a}-\mathbf{1 1} \\
\text { yield }^{b}(\%)\end{array}$ \\
\hline 1 & $2 a$ & A & 50 & 0.25 & 98 \\
\hline 2 & $2 \mathbf{a}$ & A & 20 & 15 & 97 \\
\hline 3 & $3 \mathbf{a}$ & A & 20 & 15 & 82 \\
\hline 4 & $4 a$ & $\mathrm{~A}$ & 20 & 15 & 90 \\
\hline 5 & $5 a$ & $\mathrm{~A}$ & 20 & 15 & 92 \\
\hline 6 & $2 b$ & A & 20 & 0.25 & 95 \\
\hline 7 & $3 b$ & $\mathrm{~A}$ & 20 & 0.25 & 82 \\
\hline 8 & $2 c$ & A & 20 & 0.5 & 97 \\
\hline 9 & $2 c$ & $\mathrm{C}$ & 20 & 2 & 96 \\
\hline 10 & $3 c$ & $\mathrm{C}$ & 20 & 2 & 97 \\
\hline 11 & 2d & $\mathrm{A}$ & 20 & 0.5 & 97 \\
\hline 12 & 2d & $\mathrm{C}$ & 20 & 0.5 & 95 \\
\hline 13 & $3 d$ & $\mathrm{C}$ & 20 & 0.5 & 90 \\
\hline 14 & $2 \mathrm{e}$ & A & 20 & 0.5 & 85 \\
\hline 15 & $2 \mathrm{e}$ & $\mathrm{C}$ & 20 & 1 & 75 \\
\hline 16 & $3 e$ & $\mathrm{C}$ & 20 & 1 & 91 \\
\hline 17 & $2 f$ & B & 0 & 0.5 & 91 \\
\hline 18 & $3 f$ & A & 0 & 0.5 & 90 \\
\hline 19 & $2 \mathrm{~g}$ & A & 20 & 2 & 70 \\
\hline 20 & $2 \mathrm{~g}$ & $\mathrm{C}^{c}$ & 55 & 48 & $91^{d}$ \\
\hline 21 & $3 g$ & $\mathrm{C}^{c}$ & 55 & 48 & $86^{e}$ \\
\hline 22 & $2 \mathrm{~h}$ & $\mathrm{~A}^{f}$ & 20 & 2 & 95 \\
\hline 23 & $2 \mathrm{~h}$ & $\mathrm{C}^{c}$ & 20 & 2 & 88 \\
\hline 24 & $2 \mathbf{i}$ & B & 20 & 0.5 & 89 \\
\hline 25 & $2 \mathrm{i}$ & $\mathrm{C}^{c}$ & 20 & 0.5 & 70 \\
\hline 26 & $3 \mathbf{i}$ & $\mathrm{C}^{c}$ & 20 & 1 & 90 \\
\hline 27 & $4 j$ & $\mathrm{D}$ & 55 & 5.5 & 81 \\
\hline 28 & $5 \mathbf{j}$ & $\mathrm{D}$ & 55 & 5.5 & 77 \\
\hline 29 & $4 k$ & $\mathrm{D}$ & 55 & 24 & 70 \\
\hline 30 & $5 \mathrm{k}$ & $\mathrm{D}$ & 55 & 20 & $76^{e}$ \\
\hline 31 & 41 & $\mathrm{C}^{c}$ & 20 & 18 & $88^{e}$ \\
\hline 32 & 51 & $\mathrm{C}^{c}$ & 55 & 4.5 & 94 \\
\hline
\end{tabular}

${ }^{a}$ Method A: dodecanethiol (1.5 equiv), $\mathrm{NaH}$ (3.0 equiv), $\mathrm{CH}_{3} \mathrm{CN}$. Method B: sodium dodecanethiolate (1.2 equiv), $\mathrm{CH}_{3} \mathrm{CN}$. Method C: pyrrolidine (2.0 equiv), $\mathrm{CH}_{3} \mathrm{CN}$. Method D: pyrrolidine (4.0 equiv), $\mathrm{NaH}$ (0.3 equiv), $\mathrm{CH}_{3} \mathrm{CN} .{ }^{b}$ Isolated yields after removal of reagent excess and separation from $\mathrm{Nu}-\mathrm{CH}=\mathrm{CH}-\mathrm{EWG}$ by flash column chromatography. Conversions were complete. ${ }^{c}$ With 4.0 equiv of pyrrolidine. ${ }^{d}$ Brsm yields ( $92 \%$ conversion). ${ }^{e}$ Brsm yields ( $90 \%$ conversion). ${ }^{f}$ THF as the solvent instead of $\mathrm{CH}_{3} \mathrm{CN}$. 


\section{CONCLUSIONS}

A series of heterocyclic compounds containing $\mathrm{CONHCO}, \mathrm{CONHCH}=\mathrm{CH}, \mathrm{CONHCH}=\mathrm{N}$, and $\mathrm{SO}_{2} \mathrm{NH}$ moieties react with tosylacetylene to furnish $\mathrm{N}$-2-tosylethenyl adducts (Tosvinyl or Tsv derivatives) with $Z$ configuration in the presence of $\mathrm{Et}_{3} \mathrm{~N}$ or $\mathrm{NaH}$ as catalysts. Isomeric $E$ adducts can be produced by using DMAP in stoichiometric amounts. Thus, the Z-Tsv or $E$-Tsv protecting groups can be introduced at will. Analogous derivatives and analogous protected lactams and oxazolidinones, with 2-(benzenesulfonyl)ethenyl substituents (called here Z-Besvinyl or Z-Bsv, and $E$-Besvinyl or E-Bsv), can also be stereoselectively obtained by reaction with Z- or E-1,2-bis(phenylsulfonyl)ethene, respectively. The Tsv and Bsv groups are stable in acid media and non-nucleophilic bases and can be removed efficiently via an addition-elimination mechanism by treatment with good nucleophiles such as sodium dodecanethiolate or pyrrolidine, depending on the case.

\section{EXPERIMENTAL SECTION}

General Information. Unless specified otherwise, all starting materials and reagents were obtained from commercial suppliers and used without further purification. All reactions were conducted in oven-dried glassware, under dry nitrogen, with anhydrous solvents, which were dried and distilled before use according to standard procedures. Solvents used for isolation of products and chromatography were glass distilled. Analytical thin-layer chromatography (TLC) was performed on $0.25 \mathrm{~mm}$ silica gel plates $\left(\mathrm{F}_{254}\right)$; retention factors $\left(R_{f}\right)$ are approximate. Flash column chromatography was performed on SDS silica gel $60(35-70 \mu \mathrm{m})$. Yields were determined after purification of the desired compound by column chromatography on silica gel. Melting points are uncorrected. ${ }^{1} \mathrm{H}$ NMR spectra were recorded on $400 \mathrm{MHz}$ spectrometers. Chemical shifts are reported in ppm with the solvent resonance as the internal standard $\left(\mathrm{CHCl}_{3}\right.$ impurity in $\mathrm{CDCl}_{3}, \delta 7.26 \mathrm{ppm} ; \mathrm{CD}_{3} \mathrm{SOCHD}_{2}$ in DMSO- $d_{6}, \delta$ $2.50 \mathrm{ppm})$. Data are reported in the following order: chemical shift, multiplicity $(\mathrm{s}=$ singlet, $\mathrm{d}=$ doublet, $\mathrm{t}=$ triplet, $\mathrm{q}=$ quartet, $\mathrm{br}=$ broad, $\mathrm{m}=$ multiplet), coupling constants in $\mathrm{Hz}$, integration; the aromatic protons of Ts groups (AA'XX' systems) usually appear as doublets (br $\mathrm{d}$ in the expanded spectra). ${ }^{13} \mathrm{C}$ NMR spectra were recorded in $\mathrm{CDCl}_{3}$ or DMSO on the abovementioned spectrometers $\left(100.6 \mathrm{MHz}\right.$ for $\left.{ }^{13} \mathrm{C}\right)$ with complete proton decoupling. Chemical shifts are reported in ppm with the solvent as the internal standard $\left(\mathrm{CDCl}_{3}, \delta 77.2 \mathrm{ppm}\right.$; DMSO- $\left.d_{6}, \delta 39.5 \mathrm{ppm}\right)$. Where necessary, 2D NMR experiments (HSQC and NOESY) were carried out to assist in structure elucidation and signal assignments. All the IR spectra were recorded on a FT-IR instrument equipped with an ATR accessory; only the relevant bands are reported, in $\mathrm{cm}^{-1}$. All the high-resolution mass spectra (HRMS) were obtained by the electrospray ionization (ESI+, TOF) technique. 
General procedure for the addition of imides, azinones, nucleosides and sultams to tosylacetylene, to obtain 2 . $\mathrm{Et}_{3} \mathrm{~N}$ (as a $0.1 \mathrm{M}$ solution in $\mathrm{CH}_{3} \mathrm{CN}$ ) or $\mathrm{NaH}$ was slowly added at $0{ }^{\circ} \mathrm{C}$ to a solution of the corresponding substrate and tosylacetylene (ethynyl 4-methylphenyl sulfone, 1.2 equiv) under a $\mathrm{N}_{2}$ atmosphere. The reaction was stirred at the temperature indicated in Table 1 (entries 2-9) and Table 2 until TLC analysis indicated complete consumption of the substrate. The solvent was removed under reduced pressure and the residue was dissolved in $\mathrm{CH}_{2} \mathrm{Cl}_{2}$, washed with $0.5 \mathrm{M} \mathrm{HCl}$ and brine, dried over anhyd $\mathrm{MgSO}_{4}$, filtered, and concentrated. Purification by flash column chromatography on silica gel afforded stereopure alkenes 2 .

Compound 2a (>99:1 Z/E, $78 \mathrm{mg}, 92 \%$, with 0.01 equiv of $\left.\mathrm{Et}_{3} \mathrm{~N}\right), \boldsymbol{N}$-[(Z)-2-(4-methylphenylsulfonyl)ethenyl]succinimide: white solid; mp $171-172{ }^{\circ} \mathrm{C} ; R_{f}=0.34$ (hexanes/EtOAc, $\left.20: 80\right) ;{ }^{1} \mathrm{H}$ NMR $\left(\mathrm{CDCl}_{3}\right) \delta 2.45(\mathrm{~s}, 3 \mathrm{H}), 2.88(\mathrm{~s}, 4 \mathrm{H}), 6.43(\mathrm{~d}, J=9.0$, $1 \mathrm{H}), 6.55(\mathrm{~d}, J=9.0,1 \mathrm{H}), 7.36(\mathrm{~d}, J=8.4,2 \mathrm{H}), 7.82(\mathrm{~d}, J=8.4,2 \mathrm{H}) ;{ }^{13} \mathrm{C} \mathrm{NMR}\left(\mathrm{CDCl}_{3}\right) \delta 21.8,28.9,126.2,128.3,130.0$, 130.1, 136.9, 145.4, 174.5; IR 1780, 1714, 1613; HRMS $m / z$ calcd for $\mathrm{C}_{13} \mathrm{H}_{14} \mathrm{NO}_{4} \mathrm{~S}^{+}[\mathrm{M}+\mathrm{H}]^{+} 280.0638$, found 280.0632 .

2b $\left(>99: 1 Z / E, 110 \mathrm{mg}, 89 \%\right.$, with 0.01 equiv of $\left.\mathrm{Et}_{3} \mathrm{~N}\right), \boldsymbol{N}$-[( $Z$ )-2-(4-methylphenylsulfonyl)ethenyl]phthalimide: white solid; mp $173-175^{\circ} \mathrm{C} ; R_{f}=0.55\left(\mathrm{CH}_{2} \mathrm{Cl}_{2} / \mathrm{MeOH}, 99: 1\right) ;{ }^{1} \mathrm{H} \mathrm{NMR}\left(\mathrm{CDCl}_{3}, 400 \mathrm{MHz}\right) \delta 2.43(\mathrm{~s}, 3 \mathrm{H}), 6.42(\mathrm{~d}, J=9.2,1 \mathrm{H}), 6.76$ $(\mathrm{d}, J=9.2,1 \mathrm{H}), 7.35(\mathrm{~d}, J=8.2,2 \mathrm{H}), 7.80\left(\mathrm{~m}, \mathrm{AA}^{\prime}\right.$ subsystem, $\left.2 \mathrm{H}\right), 7.86(\mathrm{~d}, J=8.2,2 \mathrm{H}), 7.96\left(\mathrm{~m}, \mathrm{BB}{ }^{\prime}, 2 \mathrm{H}\right) ;{ }^{13} \mathrm{C} \mathrm{NMR}$ $\left(\mathrm{CDCl}_{3}\right) \delta 21.8,124.4,124.9,127.9,128.3,130.0,132.1,134.9,137.5,145.1,165.4 ;$ IR $1786,1721,1590 ; \mathrm{HRMS} m / z \mathrm{calcd}$ for $\mathrm{C}_{17} \mathrm{H}_{14} \mathrm{NO}_{4} \mathrm{~S}^{+}[\mathrm{M}+\mathrm{H}]^{+} 328.0638$, found 328.0634 .

2c $\left(>99: 1 Z / E, 81 \mathrm{mg}, 85 \%\right.$, with 0.03 equiv of $\left.E_{3} \mathrm{~N}\right)$, 5'- $\boldsymbol{O}$-acetyl-3'-azido-3'-deoxy-3-[( $\left.\boldsymbol{Z}\right)$-2-(4-methylphenylsulfonyl)ethenyl]thymidine: foam; $R_{f}=0.12\left(\mathrm{CH}_{2} \mathrm{Cl}_{2} / \mathrm{MeOH}, 99: 1\right) ;{ }^{1} \mathrm{H} \mathrm{NMR}\left(\mathrm{CDCl}_{3}\right) \delta 1.97(\mathrm{br} \mathrm{d}, J=1.2,3 \mathrm{H}), 2.13(\mathrm{~s}, 3 \mathrm{H}), 2.43(\mathrm{~s}$, $3 \mathrm{H}), 2.44-2.61(\mathrm{~m}, 2 \mathrm{H}), 4.11(\mathrm{dt}, J=5.5, J=4.0,1 \mathrm{H}), 4.21(\mathrm{dt}, J=7.3, J=6.0,1 \mathrm{H}), 4.35(\mathrm{dd}, J=12.3, J=3.7,1 \mathrm{H}), 4.39$ $(\mathrm{dd}, J=12.3, J=4.4,1 \mathrm{H}), 6.09(\mathrm{t}, J=6.0,1 \mathrm{H}), 6.48(\mathrm{~d}, J=8.8,1 \mathrm{H}), 6.71(\mathrm{~d}, J=8.8,1 \mathrm{H}), 7.32(\mathrm{q}, J=1.2,1 \mathrm{H}), 7.33(\mathrm{~d}, J=$ 8.2, $2 \mathrm{H}), 7.78(\mathrm{~d}, J=8.2,2 \mathrm{H}) ;{ }^{13} \mathrm{C} \mathrm{NMR}\left(\mathrm{CDCl}_{3}\right) \delta 12.7,20.5,21.3,37.3,60.2,63.1,81.7,86.3,109.5,127.7,129.6,130.4$, 134.6, 136.4, 144.8, 148.8, 161.9, 170.0; IR 2103, 1739, 1715, 1662; HRMS m/z calcd for $\mathrm{C}_{21} \mathrm{H}_{24} \mathrm{~N}_{5} \mathrm{O}_{7} \mathrm{~S}^{+}[\mathrm{M}+\mathrm{H}]^{+} 490.1391$, found 490.1387 .

2d (98:2 Z/E, $64 \mathrm{mg}, 92 \%$, with 0.01 equiv of $\left.\mathrm{Et}_{3} \mathrm{~N}\right)$. Data for chromatographically pure $N$-[( $Z$ )-2-(4-methylphenylsulfonyl)ethenyl]-2-pyridone: white solid; mp $110-112{ }^{\circ} \mathrm{C} ; R_{f}=0.40\left(\mathrm{CH}_{2} \mathrm{Cl}_{2} / \mathrm{MeOH}, 98: 2\right) ;{ }^{1} \mathrm{H} \mathrm{NMR}\left(\mathrm{CDCl}_{3}\right) \delta 2.41(\mathrm{~s}$, $3 \mathrm{H}), 6.24(\operatorname{td} J=6.8,1.2,1 \mathrm{H}), 6.34(\mathrm{~d}, J=9.5,1 \mathrm{H}), 6.47(\mathrm{br} \mathrm{d}, J=9.4,1 \mathrm{H}), 7.30(\mathrm{~d}, J=8.2,2 \mathrm{H}), 7.33-7.39(\mathrm{~m}, 1 \mathrm{H}), 7.35(\mathrm{~d}$, 12 
$J=9.5,1 \mathrm{H}), 7.71-7.76(\mathrm{~m}, 1 \mathrm{H}), 7.73(\mathrm{~d}, J=8.2,2 \mathrm{H}) ;{ }^{13} \mathrm{C} \mathrm{NMR}\left(\mathrm{CDCl}_{3}\right) \delta 21.8,105.8,120.8,125.7,127.8,130.1,135.4$ 136.9, 138.4, 141.5, 145.5, 161.6; IR 1671, 1619; HRMS $m / z$ calcd for $\mathrm{C}_{14} \mathrm{H}_{14} \mathrm{NO}_{3} \mathrm{~S}^{+}[\mathrm{M}+\mathrm{H}]^{+} 276.0689$, found 276.0690 .

2e $\left(>99: 1 \mathrm{Z} / E, 163 \mathrm{mg}, 92 \%\right.$, with 0.01 equiv of $\left.\mathrm{Et}_{3} \mathrm{~N}\right), \mathbf{1 - [ ( Z ) - 2 - ( 4 - m e t h y l p h e n y l s u l f o n y l ) e t h e n y l ] - 2 - q u i n o x a l i n o n e : ~}$ white solid; mp $170-172{ }^{\circ} \mathrm{C} ; R_{f}=0.58\left(\mathrm{CH}_{2} \mathrm{Cl}_{2} / \mathrm{EtOAc}, 1: 1\right) ;{ }^{1} \mathrm{H} \mathrm{NMR}\left(\mathrm{CDCl}_{3}\right) \delta 2.40(\mathrm{~s}, 3 \mathrm{H}), 6.79(\mathrm{~d}, J=8.8,1 \mathrm{H}), 6.89(\mathrm{~d}, J$ $=8.8,1 \mathrm{H}), 7.19(\mathrm{dd}, J=8.4, J=1.1,1 \mathrm{H}), 7.23(\mathrm{~d}, J=8.2,2 \mathrm{H}), 7.39(\mathrm{ddd}, J=8.0, J=7.5, J=1.1,1 \mathrm{H}), 7.55(\mathrm{ddd}, J=8.4, J=$ $7.5, J=1.5,1 \mathrm{H}), 7.65(\mathrm{~d}, J=8.2,2 \mathrm{H}), 7.87(\mathrm{dd}, J=8.0, J=1.5,1 \mathrm{H}), 8.18(\mathrm{~s}, 1 \mathrm{H}) ;{ }^{13} \mathrm{C} \mathrm{NMR}\left(\mathrm{CDCl}_{3}\right) \delta 21.8,114.9,124.8$ $128.5,129.1,129.9,130.6,131.3,131.9,133.0,135.3,135.7,145.8,149.9,153.3$; IR 1678, 1607; HRMS m/z calcd for $\mathrm{C}_{17} \mathrm{H}_{15} \mathrm{~N}_{2} \mathrm{O}_{3} \mathrm{~S}^{+}[\mathrm{M}+\mathrm{H}]^{+}$327.0798, found 327.0800 .

2f $\left(95: 5 \mathrm{Z} / E, 50 \mathrm{mg}, 86 \%\right.$, with 0.03 equiv of $\left.E t_{3} \mathrm{~N}\right)$. Data for chromatographically pure 2',3',5'-tri- $\boldsymbol{O}$-acetyl-1-[( $\left.\boldsymbol{Z}\right)$-2-(4methylphenylsulfonyl)ethenyl]inosine: white solid; mp $96-98{ }^{\circ} \mathrm{C} ; R_{f}=0.45\left(\mathrm{CH}_{2} \mathrm{Cl}_{2} / \mathrm{MeOH}, 95: 5\right) ;{ }^{1} \mathrm{H} \mathrm{NMR}(\mathrm{CDCl}) \delta 2.11$ $(\mathrm{s}, 3 \mathrm{H}), 2.16(\mathrm{~s}, 6 \mathrm{H}), 2.39(\mathrm{~s}, 3 \mathrm{H}), 4.36-4.49(\mathrm{~m}, 3 \mathrm{H}), 5.57(\mathrm{t}, J=5.0,1 \mathrm{H}), 5.81(\mathrm{t}, J=5.4,1 \mathrm{H}), 6.16(\mathrm{~d}, J=5.4,1 \mathrm{H}), 6.56(\mathrm{~d}$, $J=9.2,1 \mathrm{H}), 7.29(\mathrm{~d}, J=8.2,2 \mathrm{H}), 7.36(\mathrm{~d}, J=9.2,1 \mathrm{H}), 7.72(\mathrm{~d}, J=8.2,2 \mathrm{H}), 7.96(\mathrm{~s}, 1 \mathrm{H}), 8.31(\mathrm{~s}, 1 \mathrm{H}) ;{ }^{13} \mathrm{C} \mathrm{NMR}(\mathrm{CDCl}) \delta$ $20.5,20.6,20.9,21.8,63.1,70.6,73.5,80.6,86.8,122.7,125.2,127.9,130.2,135.0,137.2,139.4,145.2,145.3,146.1,155.1$ 169.4, 169.7, 170.4; IR 1742, 1704, 1631; HRMS $m / z$ calcd for $\mathrm{C}_{25} \mathrm{H}_{27} \mathrm{~N}_{4} \mathrm{O}_{10} \mathrm{~S}^{+}[\mathrm{M}+\mathrm{H}]^{+}$575.1442, found 575.1447.

$2 \mathrm{~g}\left(>99: 1 \mathrm{Z} / E, 64 \mathrm{mg}, 87 \%\right.$, with 0.03 equiv of $\left.\mathrm{Et}_{3} \mathrm{~N}\right),(\boldsymbol{S})-\boldsymbol{N}$-[(Z)-2-(4-methylphenylsulfonyl)ethenyl]-2,10-camphorsultam: white solid; mp $131-133{ }^{\circ} \mathrm{C} ; R_{f}=0.54\left(\mathrm{CH}_{2} \mathrm{Cl}_{2} / \mathrm{MeOH}, 99.5: 0.5\right) ;{ }^{1} \mathrm{H} \mathrm{NMR}\left(\mathrm{CDCl}_{3}\right) \delta 0.91(\mathrm{~s}, 3 \mathrm{H}), 0.94(\mathrm{~s}, 3 \mathrm{H})$, $1.41-1.46(\mathrm{~m}, 1 \mathrm{H}), 1.53-1.59(\mathrm{~m}, 1 \mathrm{H}), 1.90-1.97(\mathrm{~m}, 3 \mathrm{H}), 2.25(\mathrm{dd}, J=13.7, J=8.0,1 \mathrm{H}), 2.36-2.42(\mathrm{~m}, 1 \mathrm{H}), 2.44(\mathrm{~s}, 3 \mathrm{H})$, $3.31(\mathrm{~d}, J=13.8,1 \mathrm{H}), 3.36(\mathrm{~d}, J=13.8,1 \mathrm{H}), 4.38(\mathrm{dd}, J=7.9, J=4.8,1 \mathrm{H}), 5.45(\mathrm{~d}, J=9.8,1 \mathrm{H}), 6.54(\mathrm{~d}, J=9.8,1 \mathrm{H}), 7.33$ $(\mathrm{d}, J=8.4,2 \mathrm{H}), 7.79(\mathrm{~d}, J=8.4,2 \mathrm{H}) ;{ }^{13} \mathrm{C} \mathrm{NMR}\left(\mathrm{CDCl}_{3}\right) \delta 20.1,20.2,21.8,27.0,31.9,35.0,44.4,48.3,50.0,52.7,68.1$, 111.7, 126.3, 127.5, 130.0, 139.6, 144.5; IR 1608; HRMS $m / z$ calcd for $\mathrm{C}_{19} \mathrm{H}_{26} \mathrm{NO}_{4} \mathrm{~S}_{2}{ }^{+}[\mathrm{M}+\mathrm{H}]^{+}$396.1298, found 396.1293.

2h $\left(98: 2 Z / E, 153 \mathrm{mg}, 96 \%\right.$, with 0.03 equiv of $\left.E_{3} \mathrm{~N}\right)$. Data for chromatographically pure $N$-[( $Z$ )-2-(4-methylphenylsulfonyl)ethenyl]-1,8-naphthosultam: white solid; mp $188-190{ }^{\circ} \mathrm{C} ; R_{f}=0.24\left(\mathrm{CH}_{2} \mathrm{Cl}_{2}\right) ;{ }^{1} \mathrm{H} \mathrm{NMR}\left(\mathrm{CDCl}_{3}\right) \delta 2.38(\mathrm{~s}, 3 \mathrm{H})$, $6.65(\mathrm{~d}, J=8.6,1 \mathrm{H}), 6.82(\mathrm{~d}, J=8.6,1 \mathrm{H}), 7.17(\mathrm{dd}, J=6.9, J=1.1,1 \mathrm{H}), 7.27(\mathrm{~d}, J=8.3,2 \mathrm{H}), 7.59-7.68(\mathrm{~m}, 2 \mathrm{H}), 7.77(\mathrm{dd}, J$ $=8.1, J=7.2,1 \mathrm{H}), 7.85(\mathrm{~d}, J=8.3,2 \mathrm{H}), 7.97(\mathrm{~d}, J=7.2,1 \mathrm{H}), 8.13(\mathrm{~d}, J=8.1,1 \mathrm{H}) ;{ }^{13} \mathrm{C} \mathrm{NMR}\left(\mathrm{CDCl}_{3}\right) \delta 21.8,108.4,120.2$, $120.2,120.6,127.8,128.1,128.4,129.5,129.5,130.0,130.9,131.8,132.1,135.7,137.2,145.3$; IR 1615 ; HRMS $m / z$ calcd for $\mathrm{C}_{19} \mathrm{H}_{16} \mathrm{NO}_{4} \mathrm{~S}_{2}^{+}[\mathrm{M}+\mathrm{H}]^{+} 386.0515$, found 386.0526 . 
2i (>99:1 Z/E, $103 \mathrm{mg}, 90 \%$, with 0.2 equiv of $\mathrm{NaH}), \mathbf{N}$-[(Z)-2-(4-methylphenylsulfonyl)ethenyl]saccharin: white solid; mp $168-170{ }^{\circ} \mathrm{C} ; R_{f}=0.55$ (hexanes:EtOAc, $\left.1: 1\right) ;{ }^{1} \mathrm{H}$ NMR $\left(\right.$ DMSO- $\left.d_{6}\right) \delta 2.41(\mathrm{~s}, 3 \mathrm{H}), 6.91(\mathrm{~d}, J=8.4,1 \mathrm{H}), 7.36(\mathrm{~d}, J=8.4$, $1 \mathrm{H}), 7.48(\mathrm{~d}, J=8.3,2 \mathrm{H}), 7.80(\mathrm{~d}, J=8.3,2 \mathrm{H}), 8.08(\mathrm{td}, J=7.5, J=0.6,1 \mathrm{H}), 8.14(\mathrm{td}, J=7.6, J=1.0,1 \mathrm{H}), 8.23(\mathrm{~d}, J=7.5$, $1 \mathrm{H}), 8.43(\mathrm{~d}, J=7.4,1 \mathrm{H}) ;{ }^{13} \mathrm{C}$ NMR $\left(\mathrm{DMSO}-d_{6}\right) \delta 21.1,122.0,122.0,125.9,126.1,127.9,130.0,135.1,135.8,136.4,136.5$, 136.6, 145.1, 156.4; IR 1753, 1618; HRMS (ESI+) $\mathrm{m} / z$ calcd for $\mathrm{C}_{16} \mathrm{H}_{14} \mathrm{NO}_{5} \mathrm{~S}_{2}^{+}[\mathrm{M}+\mathrm{H}]^{+}$364.0308, found 364.0314. Purification by column chromatography was not necessary (and it is not recommended, because of partial decomposition).

General procedure for the addition of imides, azinones, nucleosides and sultams to tosylacetylene, to obtain 3. Tosylacetylene (1.2 equiv) and the corresponding substrate were dissolved in $\mathrm{CH}_{3} \mathrm{CN}(0.1 \mathrm{M})$ under a $\mathrm{N}_{2}$ atmosphere. DMAP was then added and the reaction was stirred at $20^{\circ} \mathrm{C}$ or $50{ }^{\circ} \mathrm{C}$ (see Table 3) until TLC analysis indicated complete disappearance of the $Z$ isomer (usually 1 or 2 days). The solvent was removed under reduced pressure and the residue was dissolved in $\mathrm{CH}_{2} \mathrm{Cl}_{2}$. The organic layer was washed with $0.5 \mathrm{M}$ aqueous $\mathrm{HCl}$ and brine, dried over anhyd $\mathrm{MgSO}_{4}$, filtered, and concentrated. Purification by flash column chromatography on silica gel afforded pure $\mathbf{3}$.

3a $(>99: 1 E / Z, 1.36 \mathrm{~g}, 90 \%), \mathbf{1 - N}-[(E)-2-(4-m e t h y l p h e n y l s u l f o n y l) e t h e n y l]$ succinimide: white solid; $\mathrm{mp} 192-194{ }^{\circ} \mathrm{C} ; R_{f}=$ 0.51 (hexanes/EtOAc, 20:80); ${ }^{1} \mathrm{H}$ NMR $\left(\mathrm{CDCl}_{3}\right) \delta 2.43(\mathrm{~s}, 3 \mathrm{H}), 2.83(\mathrm{~s}, 4 \mathrm{H}), 7.33(\mathrm{~d}, J=8.2,2 \mathrm{H}), 7.58(\mathrm{~d}, J=14.2,1 \mathrm{H}), 7.78$ $(\mathrm{d}, J=14.2,1 \mathrm{H}), 7.78(\mathrm{~d}, J=8.2,2 \mathrm{H}) ;{ }^{13} \mathrm{C} \mathrm{NMR}\left(\mathrm{CDCl}_{3}\right) \delta 21.8,27.9,121.1,127.8,128.5,130.1,137.7,144.7,174.1 ; \mathrm{IR}$ 1731, 1622; HRMS $m / z$ calcd for $\mathrm{C}_{13} \mathrm{H}_{14} \mathrm{NO}_{4} \mathrm{~S}^{+}[\mathrm{M}+\mathrm{H}]^{+} 280.0638$, found 280.0632 .

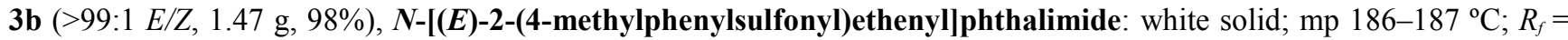
$0.77\left(\mathrm{CH}_{2} \mathrm{Cl}_{2} / \mathrm{MeOH}, 99: 1\right) ;{ }^{1} \mathrm{H} \mathrm{NMR}\left(\mathrm{CDCl}_{3}\right) \delta 2.43(\mathrm{~s}, 3 \mathrm{H}), 7.34(\mathrm{~d}, J=8.2,2 \mathrm{H}), 7.52(\mathrm{~d}, J=14.3,1 \mathrm{H}), 7.79-7.85(\mathrm{~m}, 4 \mathrm{H})$, 7.92-7.98 (m, 3H); ${ }^{13} \mathrm{C} \mathrm{NMR}\left(\mathrm{CDCl}_{3}\right) \delta 21.8,119.0,124.6,127.8,128.8,130.1,131.3,135.6,138.2,144.5,165.1 ; \mathrm{IR} 1796$, 1723, 1622; HRMS $m / z$ calcd for $\mathrm{C}_{17} \mathrm{H}_{14} \mathrm{NO}_{4} \mathrm{~S}^{+}[\mathrm{M}+\mathrm{H}]^{+} 328.0638$, found 328.0635 .

3c (>99:1 E/Z, 93 mg, 80\%), 5'-O-acetil-3'-azido-3'-deoxy-3-[(E)-2-(4-methylphenylsulfonyl)ethenyl]thymidine: white solid; mp 98-100 ${ }^{\circ} \mathrm{C} ; R_{f}=0.30\left(\mathrm{CH}_{2} \mathrm{Cl}_{2} / \mathrm{MeOH}, 99: 1\right) ;{ }^{1} \mathrm{H}$ NMR $\left(\mathrm{CDCl}_{3}\right) \delta 1.94(\mathrm{~s}, 3 \mathrm{H}), 2.12(\mathrm{~s}, 3 \mathrm{H}), 2.34-2.39(\mathrm{~m}, 1 \mathrm{H}), 2.42(\mathrm{~s}, 3 \mathrm{H}), 2.46-2.57$ $(\mathrm{m}, 1 \mathrm{H}), 4.06-4.09(\mathrm{~m}, 1 \mathrm{H}), 4.18-4.22(\mathrm{~m}, 1 \mathrm{H}), 4.32(\mathrm{dd}, J=12.4, J=3.6,1 \mathrm{H}), 4.38(\mathrm{dd}, J=12.4, J=4.4,1 \mathrm{H}), 6.05(\mathrm{t}, J=6.1,1 \mathrm{H})$, $7.31(\mathrm{~m}, 3 \mathrm{H}), 7.71(\mathrm{~d}, J=14.3,1 \mathrm{H}), 7.78(\mathrm{~d}, J=8.0,2 \mathrm{H}), 8.37(\mathrm{~d}, J=14.3,1 \mathrm{H}),{ }^{13} \mathrm{C} \mathrm{NMR}\left(\mathrm{CDCl}_{3}\right) \delta 13.5,20.9,21.7,37.9,60.4,63.2$, 82.3, 87.0, 110.1, 123.3, 127.8, 130.0, 131.8, 134.2, 138.1, 144.5, 149.1, 161.6, 170.3; IR 2109, 1739, 1718, 1651; HRMS m/z calcd for $\mathrm{C}_{21} \mathrm{H}_{24} \mathrm{~N}_{5} \mathrm{O}_{7} \mathrm{~S}^{+}[\mathrm{M}+\mathrm{H}]^{+} 490.1391$, found 490.1387 . 
3d (>99:1 E/Z, $83 \mathrm{mg}, 96 \%), \boldsymbol{N}$-[(E)-2-(4-methylphenylsulfonyl)ethenyl]-2-pyridone: white solid; mp $195-196^{\circ} \mathrm{C} ; R_{f}=$ $0.63\left(\mathrm{CH}_{2} \mathrm{Cl}_{2} / \mathrm{MeOH}, 98: 2\right) ;{ }^{1} \mathrm{H}$ NMR $\left(\mathrm{CDCl}_{3}\right) \delta 2.44(\mathrm{~s}, 3 \mathrm{H}), 6.23($ br t, $J=6.8,1 \mathrm{H}), 6.58(\mathrm{br} \mathrm{d}, J=9.1,1 \mathrm{H}), 7.06(\mathrm{~d}, J=$ $14.1,1 \mathrm{H}), 7.28-7.37(\mathrm{~m}, 4 \mathrm{H}), 7.82(\mathrm{~d}, J=8.3,2 \mathrm{H}), 8.22(\mathrm{~d}, J=14.1,1 \mathrm{H}) ;{ }^{13} \mathrm{C} \mathrm{NMR}\left(\mathrm{CDCl}_{3}\right) \delta 21.8,108.0,120.1,122.9$, 127.9, 130.2, 133.0, 137.3, 137.8, 140.0, 144.8, 161.3; IR 1682, 1625; HRMS $m / z$ calcd for $\mathrm{C}_{14} \mathrm{H}_{14} \mathrm{NO}_{3} \mathrm{~S}^{+}[\mathrm{M}+\mathrm{H}]^{+} 276.0689$, found 276.0690 .

3e (>99:1 $E / Z, 86 \mathrm{mg}, 84 \%), \mathbf{1 - [ ( E ) - 2 - ( 4 - m e t h y l p h e n y l s u l f o n y l ) e t h e n y l ] - 2 - q u i n o x a l i n o n e : ~ w h i t e ~ s o l i d ; ~ m p ~ 1 6 8 - 1 7 0 ~}{ }^{\circ} \mathrm{C}$; $R_{f}=0.66\left(\mathrm{CH}_{2} \mathrm{Cl}_{2} /\right.$ EtOAc, $\left.1: 1\right) ;{ }^{1} \mathrm{H} \mathrm{NMR}\left(\mathrm{CDCl}_{3}\right) \delta 2.44(\mathrm{~s}, 3 \mathrm{H}), 7.36(\mathrm{~d}, J=8.2,2 \mathrm{H}), 7.47(\mathrm{ddd}, J=8.1, J=7.2, J=1.3$, $1 \mathrm{H}), 7.59(\mathrm{dd}, J=8.6, J=1.4,1 \mathrm{H}), 7.65(\mathrm{ddd}, J=8.6, J=7.2, J=1.6,1 \mathrm{H}), 7.84(\mathrm{~d}, J=8.4,2 \mathrm{H}), 7.88(\mathrm{~d}, J=13.7,1 \mathrm{H}), 8.07$ $(\mathrm{d}, J=13.7,1 \mathrm{H}), 8.21(\mathrm{~s}, 1 \mathrm{H}) ;{ }^{13} \mathrm{C} \mathrm{NMR}\left(\mathrm{CDCl}_{3}\right) \delta 21.8,114.4,125.9,127.2,127.9,130.3,130.7,131.3,131.4,131.8,133.4$ 137.4, 145.0, 150.3, 154.0; IR 1681, 1612; HRMS $m / z$ calcd for $\mathrm{C}_{17} \mathrm{H}_{15} \mathrm{~N}_{2} \mathrm{O}_{3} \mathrm{~S}^{+}[\mathrm{M}+\mathrm{H}]^{+} 327.0798$, found 327.0802 .

3f (>99:1 E/Z, 52 mg, 90\%), 2',3',5'-tri-O-acetyl-1-[(E)-2-(4-methylphenylsulfonyl)ethenyl]inosine: white solid; mp 108-109 ${ }^{\circ} \mathrm{C}$; $R_{f}=0.51\left(\mathrm{CH}_{2} \mathrm{Cl}_{2} / \mathrm{MeOH}, 95: 5\right) ;{ }^{1} \mathrm{H} \mathrm{NMR}\left(\mathrm{CDCl}_{3}\right) \delta 2.09(\mathrm{~s}, 3 \mathrm{H}), 2.12(\mathrm{~s}, 3 \mathrm{H}), 2.14(\mathrm{~s}, 3 \mathrm{H}), 2.44(\mathrm{~s}, 3 \mathrm{H}), 4.35(\mathrm{dd}, J=12.3, J=4.6$, $1 \mathrm{H}), 4.39-4.47(\mathrm{~m}, 2 \mathrm{H}), 5.54(\mathrm{t}, J=5.2,1 \mathrm{H}), 5.81(\mathrm{t}, J=5.4,1 \mathrm{H}), 6.08(\mathrm{~d}, J=5.2,1 \mathrm{H}), 7.36(\mathrm{~d}, J=8.2,2 \mathrm{H}), 7.42(\mathrm{~d}, J=14.1,1 \mathrm{H}), 7.82$ $(\mathrm{d}, J=8.2,2 \mathrm{H}), 7.95(\mathrm{~s}, 1 \mathrm{H}), 8.10(\mathrm{~s}, 1 \mathrm{H}), 8.14(\mathrm{~d}, J=14.1,1 \mathrm{H}) ;{ }^{13} \mathrm{C} \mathrm{NMR}\left(\mathrm{CDCl}_{3}\right) \delta 20.5,20.7,20.9,21.8,63.0,70.6,73.6,80.6,86.5$, $124.5,127.9,128.9,130.3,132.6,136.2,138.5,145.9,147.5,147.6,155.3,169.4,169.7,170.4$; IR 1748, 1712; HRMS m/z calcd for $\mathrm{C}_{25} \mathrm{H}_{27} \mathrm{~N}_{4} \mathrm{O}_{10} \mathrm{~S}^{+}[\mathrm{M}+\mathrm{H}]^{+}$575.1442, found 575.1447.

3g (>99:1 E/Z, $580 \mathrm{mg}, 82 \%),(\boldsymbol{S})-\mathrm{N}$-[(E)-2-(4-methylphenylsulfonyl)ethenyl]-2,10-camphorsultam: white solid; mp 97$98{ }^{\circ} \mathrm{C} ; R_{f}=0.68\left(\mathrm{CH}_{2} \mathrm{Cl}_{2} / \mathrm{MeOH}, 99.5: 0.5\right) ;{ }^{1} \mathrm{H} \mathrm{NMR}\left(\mathrm{CDCl}_{3}\right) \delta 0.95(\mathrm{~s}, 3 \mathrm{H}), 1.02(\mathrm{~s}, 3 \mathrm{H}), 1.31(\mathrm{t}, J=8.3,1 \mathrm{H}), 1.43(\mathrm{t}, J=$ $9.1,1 \mathrm{H}), 1.81(\mathrm{dd}, J=12.9, J=7.9,1 \mathrm{H}), 1.90-1.95(\mathrm{~m}, 3 \mathrm{H}), 2.07-2.15(\mathrm{~m}, 1 \mathrm{H}), 2.41(\mathrm{~s}, 3 \mathrm{H}), 3.31(\mathrm{~d}, J=13.9,1 \mathrm{H}), 3.36(\mathrm{~d}, J$ $=13.8,1 \mathrm{H}), 3.48(\mathrm{dd}, J=7.8, J=4.8,1 \mathrm{H}), 5.70(\mathrm{~d}, J=13.6,1 \mathrm{H}), 7.30(\mathrm{~d}, J=8.2,2 \mathrm{H}), 7.51(\mathrm{~d}, J=13.6,1 \mathrm{H}), 7.74(\mathrm{~d}, J=8.2$, $2 \mathrm{H}) ;{ }^{13} \mathrm{C} \mathrm{NMR}\left(\mathrm{CDCl}_{3}\right) \delta 20.0,20.4,21.7,26.8,32.3,35.9,44.7,48.1,50.3,50.7,64.5,110.7,127.4,130.0,134.8,139.0$, 144.0; IR 1609; HRMS $m / z$ calcd for $\mathrm{C}_{19} \mathrm{H}_{26} \mathrm{NO}_{4} \mathrm{~S}_{2}{ }^{+}[\mathrm{M}+\mathrm{H}]^{+} 396.1298$, found 396.1293.

3h (>99:1 E/Z, $56 \mathrm{mg}, 97 \%), \boldsymbol{N}$-[(E)-2-(4-methylphenylsulfonyl)ethenyl]-1,8-naphthosultam: white solid; mp 181-183 ${ }^{\circ} \mathrm{C} ; R_{f}=0.30\left(\mathrm{CH}_{2} \mathrm{Cl}_{2}\right) ;{ }^{1} \mathrm{H} \mathrm{NMR}\left(\mathrm{CDCl}_{3}\right) \delta 2.44(\mathrm{~s}, 3 \mathrm{H}), 6.72(\mathrm{~d}, J=13.9,1 \mathrm{H}), 7.18(\mathrm{~m}, 1 \mathrm{H}), 7.35(\mathrm{~d}, J=8.4,2 \mathrm{H}), 7.66-7.68$ $(\mathrm{m}, 2 \mathrm{H}), 7.80-7.86(\mathrm{~m}, 1 \mathrm{H}), 7.84(\mathrm{~d}, J=8.4,2 \mathrm{H}), 7.90(\mathrm{~d}, J=13.9,1 \mathrm{H}), 8.02(\mathrm{~d}, J=7.3,1 \mathrm{H}), 8.18(\mathrm{~d}, J=8.4,1 \mathrm{H}) ;{ }^{13} \mathrm{C} \mathrm{NMR}$ 
$\left(\mathrm{CDCl}_{3}, 100.6 \mathrm{MHz}\right) \delta 21.8,105.6,112.5,118.8,120.5,121.4,127.6,128.6,128.9,129.5,130.1,130.6,131.0,132.3,132.5$, 138.5, 144.4; IR 1622; HRMS $m / z$ calcd for $\mathrm{C}_{19} \mathrm{H}_{16} \mathrm{NO}_{4} \mathrm{~S}_{2}{ }^{+}[\mathrm{M}+\mathrm{H}]^{+} 386.0515$, found 386.0525.

$N$-[(E)-2-(4-Methylphenylsulfonyl)ethenyl] saccharin, 3i. A solution of DMAP (4 mg, $0.03 \mathrm{mmol})$ and $2 \mathbf{i}(228 \mathrm{mg}, 0.627$ mmol) in $\mathrm{CH}_{3} \mathrm{CN}(6.3 \mathrm{~mL})$ was stirred overnight at $\mathrm{rt}$. The solvent was removed under reduced pressure and the residue was purified by flash column chromatography (hexanes:EtOAc, 1:1) to afford $3 \mathbf{i}$ (205 $\mathrm{mg}, 90 \%,>99: 1 \mathrm{E} / \mathrm{Z}$ ) as a white solid: $\mathrm{mp}$ 208-209 ${ }^{\circ} \mathrm{C} ; R_{f}=0.54$ (hexanes/EtOAc, $\left.1: 1\right) ;{ }^{1} \mathrm{H}$ NMR $\left(\mathrm{CDCl}_{3}\right) \delta 2.45(\mathrm{~s}, 3 \mathrm{H}), 6.93(\mathrm{~d}, J=14.3,1 \mathrm{H}), 7.36(\mathrm{~d}, J=8.0,2 \mathrm{H})$, $7.83(\mathrm{~d}, J=8.0,2 \mathrm{H}), 7.92-8.00(\mathrm{~m}, 4 \mathrm{H}), 8.17(\mathrm{~d}, J=7.3,1 \mathrm{H}) ;{ }^{13} \mathrm{C} \mathrm{NMR}\left(\mathrm{CDCl}_{3}\right) \delta 21.8,118.0,121.6,126.0,126.5,127.0$, 127.9, 130.2, 135.4, 136.3, 137.3, 137.6, 144.9, 156.2; IR 1739, 1623; HRMS $m / z$ calcd for $\mathrm{C}_{16} \mathrm{H}_{14} \mathrm{NO}_{5} \mathrm{~S}_{2}{ }^{+}[\mathrm{M}+\mathrm{H}]^{+} 364.0308$, found 364.0304 .

General procedure for the preparation of 4. LiHMDS (1.5 equiv, 1.0 M in THF) was added dropwise to a solution of the substrate in THF $(0.1 \mathrm{M})$ under a $\mathrm{N}_{2}$ atmosphere at $0{ }^{\circ} \mathrm{C}$. (Z)-1,2-Bis(phenylsulfonyl)ethene (1.5 equiv) was then slowly added and the reaction was stirred until TLC analysis indicated complete consumption of the starting material (a few minutes). The reaction mixture was diluted with $\mathrm{H}_{2} \mathrm{O}$ and extracted with EtOAc. The combined organic layers were washed with brine, dried over anhyd $\mathrm{MgSO}_{4}$, filtered, and concentrated. The residue was purified by flash column chromatography on silica gel.

4a (93:7 Z:E, $97 \mathrm{mg}, 95 \%)$. Data for chromatographically pure 1-[(Z)-2-(phenylsulfonyl)ethenyl]succinimide, 4a: white solid; mp 118-120 ${ }^{\circ} \mathrm{C} ; R_{f}=0.48$ (hexanes/EtOAc, 20:80); ${ }^{1} \mathrm{H}$ NMR $\left(\mathrm{CDCl}_{3}\right) \delta 2.88(\mathrm{~s}, 4 \mathrm{H}), 6.44(\mathrm{~d}, J=9.0,1 \mathrm{H}), 6.58(\mathrm{~d}, J=$ 9.0, 1H), 7.54-7.59 (m, 2H), 7.63-7.70 (m, 1H), 7.92-7.97 (m, 2H); ${ }^{13} \mathrm{C}$ NMR $\left(\mathrm{CDCl}_{3}\right) \delta 28.9,126.6,128.2,129.4,129.7$, 134.3, 139.8, 174.5; IR 1730, 1637; HRMS (ESI+) $m / z$ calcd for $\mathrm{C}_{12} \mathrm{H}_{12} \mathrm{NO}_{4} \mathrm{~S}^{+}[\mathrm{M}+\mathrm{H}]^{+} 266.0482$, found 266.0486.

4j (94:6 Z/E, $155 \mathrm{mg}, 95 \%)$. Data for chromatographically pure 1-[(Z)-2-(phenylsulfonyl)ethenyl]-2-pyrrolidinone: white solid; mp 116-118 ${ }^{\circ} \mathrm{C} ; R_{f}=0.52\left(\mathrm{CH}_{2} \mathrm{Cl}_{2} / \mathrm{MeOH}, 99: 1\right) ;{ }^{1} \mathrm{H}$ NMR $\left(\mathrm{CDCl}_{3}\right) \delta 2.08-2.18(\mathrm{~m}, 2 \mathrm{H}), 2.50(\mathrm{t}, J=8.1,2 \mathrm{H}), 4.22(\mathrm{t}, J$ $=7.3,2 \mathrm{H}), 5.58(\mathrm{~d}, J=10.7,1 \mathrm{H}), 7.19(\mathrm{~d}, J=10.7,1 \mathrm{H}), 7.53-7.59(\mathrm{~m}, 2 \mathrm{H}), 7.61-7.66(\mathrm{~m}, 1 \mathrm{H}), 7.91-7.96(\mathrm{~m}, 2 \mathrm{H}) ;{ }^{13} \mathrm{C} \mathrm{NMR}$ $\left(\mathrm{CDCl}_{3}\right) \delta 18.3,29.9,48.9,108.2,126.9,129.3,130.8,133.3,142.6,175.8 ;$ IR 1721, 1603; HRMS (ESI +$) \mathrm{m} / z$ calcd for $\mathrm{C}_{12} \mathrm{H}_{14} \mathrm{NO}_{3} \mathrm{~S}^{+}[\mathrm{M}+\mathrm{H}]^{+}: 252.0689$, found: 252.0691 .

4k (90:10 Z/E, 109 mg, 90\%). Data for chromatographically pure 5-tert-butyldiphenylsilyloxymethyl- $N$-[(Z)-2-(phenylsulfonyl)ethenyl]-2-pyrrolidinone: white solid; mp $160-162{ }^{\circ} \mathrm{C} ; R_{f}=0.80\left(\mathrm{CH}_{2} \mathrm{Cl}_{2} / \mathrm{EtOAc}, 1: 1\right) ;{ }^{1} \mathrm{H} \mathrm{NMR}\left(\mathrm{CDCl}_{3}\right) \delta 1.00(\mathrm{~s}$, 9H), 2.09-2.33 (m, 2H), 2.45 (ddd, $J=17.9, J=10.2, J=2.1,1 \mathrm{H}), 2.80(\mathrm{dt}, J=17.9, J=10.2,1 \mathrm{H}), 3.58(\mathrm{dd}, J=11.4, J=1.9$, $1 \mathrm{H}), 3.87(\mathrm{dd}, J=11.4, J=2.2,1 \mathrm{H}), 5.09(\mathrm{br} \mathrm{d}, J=8.9,1 \mathrm{H}), 5.40(\mathrm{~d}, J=10.8,1 \mathrm{H}), 6.98(\mathrm{~d}, J=10.8,1 \mathrm{H}), 7.31-7.36(\mathrm{~m}, 2 \mathrm{H})$, 
7.37-7.47 (m, 6H), 7.48-7.52 (m, 3H), 7.54-7.57 (m, 2H), 7.72-7.76 (m, 2H); ${ }^{13} \mathrm{C} \mathrm{NMR}\left(\mathrm{CDCl}_{3}\right) \delta 19.1,21.5,26.9,30.2$, $59.8,64.3,109.3,126.9,127.8,127.9,129.2,130.0,130.0,132.6,132.9,133.3,135.7,135.8,141.9,176.6$; IR 1713, 1605; HRMS $m / z$ calcd for $\mathrm{C}_{29} \mathrm{H}_{34} \mathrm{NO}_{4} \mathrm{SSi}^{+}[\mathrm{M}+\mathrm{H}]^{+}: 520.1972$, found 520.1976 .

4l (94:6 Z/E, $139 \mathrm{mg}, 90 \%)$. Data for chromatographically pure (S)-4-benzyl-3-[(Z)-2-(phenylsulfonyl)ethenyl]-1,3oxazolidin-2-one: white solid; mp $119-121^{\circ} \mathrm{C} ; R_{f}=0.76\left(\mathrm{CH}_{2} \mathrm{Cl}_{2} / \mathrm{MeOH}, 99: 1\right) ;{ }^{1} \mathrm{H} \mathrm{NMR}\left(\mathrm{CDCl}_{3}\right) \delta 2.64(\mathrm{dd}, J=13.3, J=$ $10.3,1 \mathrm{H}), 3.58(\mathrm{dd}, J=13.3, J=3.4,1 \mathrm{H}), 4.21-4.23(\mathrm{~m}, 2 \mathrm{H}), 5.50(\mathrm{~m}, 1 \mathrm{H}), 5.61(\mathrm{~d}, J=10.8,1 \mathrm{H}), 7.02(\mathrm{~d}, J=10.8,1 \mathrm{H})$, 7.23-7.27 (m, 1H), 7.29-7.37 (m, 4H), 7.52-7.58 (m, 2H), 7.60-7.66 (m, 1H), 7.94-7.98 (m, 2H); ${ }^{13} \mathrm{C} \mathrm{NMR}\left(\mathrm{CDCl}_{3}\right) \delta 36.4$, 57.4, 66.2, 109.3, 127.1, 127.3, 128.9, 129.4, 129.8, 130.0, 133.7, 135.0, 141.6, 155.6; IR 1762, 1617; HRMS $\mathrm{m} / \mathrm{z}$ calcd for $\mathrm{C}_{18} \mathrm{H}_{18} \mathrm{NO}_{4} \mathrm{~S}^{+}[\mathrm{M}+\mathrm{H}]^{+}: 344.0951$, found 344.0954 .

General procedure for the preparation of 5. $\mathrm{NaH}$ (1.1 equiv) and 15-crown-5 (1.5 equiv) were added to a solution of the substrate in THF $(0.1 \mathrm{M})$ under a $\mathrm{N}_{2}$ atmosphere at $0{ }^{\circ} \mathrm{C} .(E)$-1,2-Bis(phenylsulfonyl)ethene (which is rather insoluble in most solvents, 1.3 equiv) was then added in portions and the reaction was stirred at $\mathrm{rt}$ until TLC analysis indicated complete consumption of the starting material (around 4 h). The reaction mixture was diluted with $\mathrm{H}_{2} \mathrm{O}$ and extracted with $\mathrm{CH}_{2} \mathrm{Cl}_{2}$. The combined organic fractions were washed with brine, dried over anhyd $\mathrm{MgSO}_{4}$, filtered, and concentrated. The residue was purified by flash column chromatography on silica gel.

5a (>99:1 E:Z, 99 mg, 97\%); 1-[(E)-2-(phenylsulfonyl)ethenyl]succinimide, 5a: white solid; mp 186-187 ${ }^{\circ} \mathrm{C} ; R_{f}=0.32$ (hexanes/EtOAc, 20:80); ${ }^{1} \mathrm{H}$ NMR $\left(\mathrm{CDCl}_{3}\right) \delta 2.83(\mathrm{~s}, 4 \mathrm{H}), 7.52-7.57(\mathrm{~m}, 2 \mathrm{H}), 7.59(\mathrm{~d}, J=14.2,1 \mathrm{H}), 7.60-7.65(\mathrm{~m}, 1 \mathrm{H}), 7.82$ $(\mathrm{d}, J=14.2,1 \mathrm{H}), 7.90-7.93(\mathrm{~m}, 2 \mathrm{H}) ;{ }^{13} \mathrm{C} \mathrm{NMR}\left(\mathrm{CDCl}_{3}\right) \delta 27.9,121.0,127.8,128.9,129.5,133.7,140.7,173.9 ; \mathrm{IR} 1715$, 1621, 1365, 1132; HRMS (ESI+) $m / z$ calcd for $\mathrm{C}_{12} \mathrm{H}_{12} \mathrm{NO}_{4} \mathrm{~S}+[\mathrm{M}+\mathrm{H}]^{+}$266.0482, found 266.0485.

5j (>99:1 E/Z, 570 mg, 91\%), 1-[(E)-2-(phenylsulfonyl)ethenyl]-2-pyrrolidinone: white solid; mp 143-145 ${ }^{\circ} \mathrm{C} ; R_{f}=0.39$ $\left(\mathrm{CH}_{2} \mathrm{Cl}_{2} / \mathrm{MeOH}, 99: 1\right) ;{ }^{1} \mathrm{H}$ NMR $\left(\mathrm{CDCl}_{3}\right) \delta 2.09-2.17(\mathrm{~m}, 2 \mathrm{H}), 2.52(\mathrm{t}, J=8.2,2 \mathrm{H}), 3.47(\mathrm{t}, J=7.3,2 \mathrm{H}), 5.72(\mathrm{~d}, J=13.7$, 1H), 7.46-7.52 (m, 2H), 7.54-7.59 (m, 1H), 7.84-7.87 (m, 2H), $8.05(\mathrm{~d}, J=13.7,1 \mathrm{H}) ;{ }^{13} \mathrm{C} \mathrm{NMR}\left(\mathrm{CDCl}_{3}\right) \delta 17.5,30.8,45.2$, 110.2, 127.2, 129.3, 133.1, 136.2, 142.0, 174.4; IR 1727, 1610; HRMS (ESI+) $m / z$ calcd for $\mathrm{C}_{12} \mathrm{H}_{14} \mathrm{NO}_{3} \mathrm{~S}^{+}[\mathrm{M}+\mathrm{H}]^{+}: 252.0689$, found: 252.0693 .

5k (>99:1 E/Z, 133 mg, 90\%), 5-tert-butyldiphenylsilyloxymethyl- $N$-[(E)-2-(phenylsulfonyl)ethenyl]-2-pyrrolidinone: white solid; mp $164-165{ }^{\circ} \mathrm{C} ; R_{f}=0.73\left(\mathrm{CH}_{2} \mathrm{Cl}_{2} / \mathrm{EtOAc}, 1: 1\right) ;{ }^{1} \mathrm{H} \mathrm{NMR}\left(\mathrm{CDCl}_{3}\right) \delta 0.99(\mathrm{~s}, 9 \mathrm{H}), 2.16-2.22(\mathrm{~m}, 2 \mathrm{H}), 2.41-2.50$ 
(m, 1H), $2.74(\mathrm{dt}, J=17.9, J=10.3,1 \mathrm{H}), 3.57(\mathrm{dd}, J=10.9, J=2.9,1 \mathrm{H}), 3.76(\mathrm{dd}, J=10.9, J=4.2,1 \mathrm{H}), 3.84-3.91(\mathrm{~m}, 1 \mathrm{H})$, $5.75(\mathrm{~d}, J=14.0,1 \mathrm{H}), 7.33-7.39(\mathrm{~m}, 4 \mathrm{H}), 7.40-7.45(\mathrm{~m}, 2 \mathrm{H}), 7.47-7.52(\mathrm{~m}, 4 \mathrm{H}), 7.53-7.59(\mathrm{~m}, 3 \mathrm{H}), 7.78-7.81(\mathrm{~m}, 2 \mathrm{H}), 7.99$ $(\mathrm{d}, J=14.0,1 \mathrm{H}) ;{ }^{13} \mathrm{C} \mathrm{NMR}\left(\mathrm{CDCl}_{3}\right) \delta 19.2,22.0,26.8,30.5,58.5,62.8,110.4,127.2,128.1,128.1,129.2,129.9,130.2,130.3$, 132.1, 132.7, 132.9, 135.5, 135.5, 135.6, 142.2, 175.1; IR 1730, 1612; HRMS $m / z$ calcd for $\mathrm{C}_{29} \mathrm{H}_{34} \mathrm{NO}_{4} \mathrm{SSi}^{+}[\mathrm{M}+\mathrm{H}]^{+}$: 520.1972, found 520.1976 .

51 (>99:1 E/Z, 170 mg, 96\%), (S)-4-benzyl-3-[(E)-2-(phenylsulfonyl)ethenyl]-1,3-oxazolidin-2-one: white solid; mp 162$163{ }^{\circ} \mathrm{C} ; R_{f}=0.63\left(\mathrm{CH}_{2} \mathrm{Cl}_{2} / \mathrm{MeOH}, 99: 1\right) ;{ }^{1} \mathrm{H} \mathrm{NMR}\left(\mathrm{CDCl}_{3}\right) \delta 2.83(\mathrm{dd}, J=14.0, J=7.9,1 \mathrm{H}), 3.09(\mathrm{dd}, J=14.0, J=4.1,1 \mathrm{H})$, $4.23-4.30(\mathrm{~m}, 2 \mathrm{H}), 4.31-4.36(\mathrm{~m}, 1 \mathrm{H}), 5.93(\mathrm{~d}, J=13.9,1 \mathrm{H}), 7.10(\mathrm{~d}, J=8.1,2 \mathrm{H}), 7.20-7.30(\mathrm{~m}, 3 \mathrm{H}), 7.52-7.57(\mathrm{~m}, 2 \mathrm{H})$, 7.59-7.64 (m, 1H), $7.82(\mathrm{~d}, J=13.9,1 \mathrm{H}), 7.89(\mathrm{~d}, J=8.1,2 \mathrm{H}) ;{ }^{13} \mathrm{C} \mathrm{NMR}\left(\mathrm{CDCl}_{3}\right) \delta 37.2,55.7,67.4,110.7,127.4,127.9$, 129.3, 129.3, 129.4, 133.3, 134.1, 136.6, 141.8, 154.2; IR 1749, 1614; HRMS $m / z$ calcd for $\mathrm{C}_{18} \mathrm{H}_{18} \mathrm{NO}_{4} \mathrm{~S}^{+}[\mathrm{M}+\mathrm{H}]^{+}: 344.0951$, found: 344.0954 .

Removal of the Tsv group. Method A. A suspension of dodecanethiol (1.5 equiv) and $\mathrm{NaH}$ (3.0 equiv) in $\mathrm{CH}_{3} \mathrm{CN}_{\text {was }}$ added to a solution of the protected substrate in anhyd $\mathrm{CH}_{3} \mathrm{CN}(0.1 \mathrm{M})$. The resulting mixture was stirred at the temperature shown in Table 4 until TLC indicated complete consumption of the starting material. The reaction was quenched with water, neutralized with $0.5 \mathrm{M}$ aqueous $\mathrm{HCl}$, and extracted with $\mathrm{CH}_{2} \mathrm{Cl}_{2}$. The combined organic extracts were washed with brine, dried over $\mathrm{MgSO}_{4}$, filtered, and concentrated. The residue was purified by flash column chromatography on silica gel.

Removal of the Tsv group. Method B. A suspension of sodium 1-dodecanethiolate (1.2 equiv) in $\mathrm{CH}_{3} \mathrm{CN}$ was added to a solution of the protected substrate in anhyd $\mathrm{CH}_{3} \mathrm{CN}(0.1 \mathrm{M})$. TLC indicated complete consumption of the starting material after stirring at $0{ }^{\circ} \mathrm{C}$ or $\mathrm{rt}$ for a few minutes (see Table 4). The reaction was quenched with water, neutralized with $0.5 \mathrm{M}$ aqueous $\mathrm{HCl}$, and extracted with $\mathrm{CH}_{2} \mathrm{Cl}_{2}$. The combined organic extracts were washed with brine, dried over $\mathrm{MgSO}_{4}$, filtered, and concentrated. The residue was purified by flash column chromatography on silica gel.

Removal of the Tsv and Bsv groups. Method C. Pyrrolidine (2.0 equiv) was added to a solution of the protected substrate in anhyd $\mathrm{CH}_{3} \mathrm{CN}(0.1 \mathrm{M})$ and the mixture was stirred at $\mathrm{rt}$ or $55^{\circ} \mathrm{C}$ (see Table 4) until TLC indicated complete consumption of the starting material. The solvent was removed under reduced pressure and the residue was purified by flash column chromatography on silica gel.

Removal of the Tsv and Bsv groups. Method D. Pyrrolidine (2.0 equiv) and $\mathrm{NaH}$ ( 0.3 equiv) were added to a solution of the protected substrate in anhyd $\mathrm{CH}_{3} \mathrm{CN}(0.1 \mathrm{M})$. The mixture was stirred at $55{ }^{\circ} \mathrm{C}$ until TLC indicated complete consumption 
of the starting material. The solvent was removed under reduced pressure and the residue was purified by flash column chromatography on silica gel.

\section{ASSOCIATED CONTENT}

\section{Supporting Information}

Copies of ${ }^{1} \mathrm{H}$ and ${ }^{13} \mathrm{C}$ NMR spectra of the new compounds. This material is available free of charge at http://pubs.acs.org.

\section{AUTHOR INFORMATION}

\section{Corresponding Authors}

*E-mail: (A.M.C.) amcosta@ub.edu, (J.V.)jvilarrasa@ub.edu

\section{Notes}

The authors declare no competing financial interest.

\section{ACKNOWLEDGMENTS}

Grants CTQ2009-13590 (Spanish Government, Madrid), 2009SGR825 (AGAUR), and CTQ2012-39230 are acknowledged. David de Vicente carried out preliminary experiments during his Master Thesis. L.M. holds a UB studentship.

\section{REFERENCES}

(1) For reviews, see: (a) Back, T. G.; Clary, K.-N.; Gao, D. Chem. Rev. 2010, 110, 4498-4553. (b) Zhu, Q.; Lu, Y. Austral. J. Chem. 2009, 62, 951-955. (c) Back, T. G. Tetrahedron 2001, 57, 5263-5301. For reviews of organocatalytic conjugate additions (with sections on vinyl sulfones), see: (d) Sulzer-Mosse, S.; Alexakis, A. Chem. Commun. 2007, 3123-3135. (e) Almasi, D.; Alonso, D. A.; Nájera, C. Tetrahedron: Asymmetry 2007, 18, 299-365. For pioneering additions of amines to conjugate acetylenic sulfones, see: (e) Truce, W. E.; Brady, D. G. J. Org, Chem. 1966, 31, 3543-3550. (f) Stirling, C. J. M. J. Chem. Soc. 1964, 5863-5869.

(2) For the conjugate additions of CONHCO and CONH groups to methyl propynoate (methyl propiolate), see: Mola, L.; Font, J.; Bosch, L.; Caner, J.; Costa, A. M.; Etxebarría-Jardí, G.; Pineda, O.; de Vicente, D.; Vilarrasa, J. J. Org. Chem. 2013, $78,5832-5842$, and references cited therein.

(3) The Tosvinyl group was abbreviated as Tsv in: Wuts, P. G. M.; Greene, T. W. Protective Groups in Organic Synthesis, 4th Ed.; Wiley: Hoboken, 2007, p. 899.

(4) Arjona, O.; Iradier, F.; Medel, R.; Plumet, J. J. Org. Chem. 1999, 64, 6090-6093. (b) Arjona, O.; Medel, R.; Rojas, J. K.; Costa, A. M.; Vilarrasa, J. Tetrahedron Lett. 2003, 44, 6369-6372. (c) Medel, R.; Monterde, M. I., Plumet, J.; Rojas, J. K. J. Org. Chem. 2005, 70, 735-738. Also see: (d) Medel, R.; Plumet, J. Synthesis 2006, 1339-1342.

(5) The updated summary is that thiols, at $\mathrm{rt}$, with only a trace amount of $\mathrm{Et}_{3} \mathrm{~N}$ afford almost exclusively Z-Tsv protected compounds, whereas sodium thiolates give rise almost exclusively to $E$-Tsv derivatives. In general, conjugate additions to tosylacetylene afford the kinetically controlled cis products (isomers $Z$ ) via trans addition, whereas isomerization via additionelimination can lead to the thermodynamically more stable $E$ isomers. 
(6) Additions to tosylacetylene: (a) Back, T. G.; Parvez, M.; Wulff, J. E. J. Org. Chem. 2003, 68, 2223-2233 (amides). (b) Dransfield, P. J.; Dilley, A. S.; Wang, S.; Romo, D. Tetrahedron 2006, 62, 5223-5247 (protection of a cyclic urea, viz. imidazol-2-one). (c) Gao, D.; Parvez, M.; Back, T. G. Chem. Eur. J. 2010, 16, 14281-14284 (amides). (d) Gao, D.; Back, T. G. Chem. Eur. J. 2012, 18, 14828-14840 (amides). (e) Khong, S.; Kwon, O. J. Org. Chem. 2012, 77, 8257-8267 (sulfonamides). For additions to other sulfonylacetylenes: (f) Hasegawa, K.; Hirooka, S.; Kawahara, H.; Nakayama, A.; Ishikawa, K.; Takeda, N.; Mukai, H. Bull. Chem. Soc. Jpn. 1978, 51, 1805-1810 (intramolecular Michael addition of ureas). (g) Xiang, J.; Jiang, W.; Gong, J.; Fuchs, P. L. J. Am. Chem. Soc. 1997, 119, 4123-4129 (phthalimide + phenylethynyl trifluoromethyl sulfone). (h) Back, T. G.; Wulff, J. E. Chem. Comm. 2002, 1710-1711 (amides to alkynyl p-tolyl sulfones). For additions followed by rearrangements, see: (i) Weston, M. H.; Parvez, M.; Back, T. G. J. Org. Chem. 2010, 75, 54025405. (j) Tayama, E.; Igarashi, T.; Iwamoto, H.; Hasegawa, E. Org. Biomol. Chem. 2012, 10, 339-345, and references therein.

(7) Dransfield, P. J.; Wang, S.; Dilley, A.; Romo, D. Org. Lett. 2005, 7, 1679-1682.

(8) For reviews and relevant works on the relative nucleophilicity of neutral nitrogen bases (DABCO $>$ DMAP $>>\mathrm{Et}_{3} \mathrm{~N}>>$ DIPEA) and on their basicities in aqueous media (DABCO $<$ DMAP $<\mathrm{Et}_{3} \mathrm{~N}<\mathrm{DIPEA}$ ), see: (a) Mayr, H.; Lakhdar, S.; Maji, B.; Ofial, A. R. Beilst. J. Org. Chem. 2012, 8, 1458-1478. (b) De Rycke, N.; Couty, F.; David, O. R. P. Chem. Eur. J. 2011, 17, 12852-12871. (c) Baidya, M.; Mayr, H. Chem. Commun. 2008, 1792-1794. (d) Aggarwal, V. K.; Emme, I.; Fulford, S. Y. J. Org. Chem. 2003, 68, 692-700.

(9) We attribute this fact to the higher tendency of DABCO to be involved in the concomitant formation of a tosylacetylene dimer ( $\mathrm{Ts}-\mathrm{C} \equiv \mathrm{C}-\mathrm{CH}=\mathrm{CH}-\mathrm{Ts}, \delta 6.72$ and $6.93,{ }^{3} \mathrm{~J}=15.4 \mathrm{~Hz}$, which we have confirmed by blank experiments with $\mathrm{Ts}-\mathrm{C} \equiv \mathrm{CH}$ and catalytic amounts of $\mathrm{DABCO}$ ) and subsequent additions, including polymerization, which also makes the separation of the desired product more difficult. There is only one precedent of a similar dimerization: (a) Sardari, S.; Khalaj, V.; Khomeini, M. M.; Azerang, P. U.S. Patent 2013 8,569,361B1. By contrast, dimerizations of propynoate esters are much better known: (b) Ramachandran, P. V.; Rudd, M. T.; Reddy, M. V. R. Tetrahedron Lett. 2005, 46, 2547-2549, and references cited therein. (c) Ref. 2 (and ref. 10 cited therein).

(10) (Z)-Bis(phenylsulphonyl)ethene (purchased from TCI Europe) was nearly a 98:2 Z/E mixture by ${ }^{1} \mathrm{H}$ NMR. Isomer $E$ (also purchased from TCI Europe) was $>99 \%$ pure. There are precedents of stereospecific reactions of these two reagents with nucleophiles. See: (a) Knapp, S.; Levorse, A. T. J. Org. Chem. 1988, 53, 4006-4014 (5-iodomethyl-2-pyrrolidinone). For reaction with 1,3-oxazolidine-2-thiones or a derivative of 1,3-oxazine-2-thione, see: (b) Girniene, J.; Tardy, S.; Tatibouët, A.; Sačkus, A.; Rollin, P. Tetrahedron Lett. 2004, 45, 6443-6446. (c) Tardy, S.; Tatibouët, A.; Rollin, P.; Dujardin, G. Synlett. 2006, 45, 1425-1427. (d) Leconte, N.; Silva, S.; Tatibouët, A.; Rauter, A. P.; Rollin, P. Synlett 2006, 301-305.

(11) Similarly, we prepared stereopure samples of $Z$-Bsv and $E$-Bsv derivatives of $\mathbf{1 f}$ (that is, compounds $\mathbf{4 f}$ and $\mathbf{5 f}$ ), to confirm that the procedure is general and can be applied to nucleosides. Results not included for simplicity's sake.

(12) (a) Bell, R. P.; Higginson, W. C. E. Proc. R. Soc. A 1949, 197, 141-159. (b) Bordwell, F. G. Acc. Chem. Res. 1988, $21,456-463$.

(13) Reactions of saccharine with dimethyl acetylenedicarboxylate and related triple bonds have been reported: (a) Yavari, I.; Alizadeh, A.; Anary-Abbasinejad, M. Tetrahedron Lett. 2002, 43, 9449-9452. (b) Maghsoodlou, M. T.; Heydari, R.; Habibi-Khorassani, S. M.; Hazeri, N.; Lashkari, M.; Rostamizadeh, M.; Sajadikhah, S. S. Synth. Commun. 2011, 41, $569-578$. (c) Shajari, N.; Ramazani, A. Asian J. Chem. 2007, 19, 1581-1583. 
(14) For example, heating $\mathbf{2 b}$ with 0.5 equiv of DMAP, in $\mathrm{CH}_{3} \mathrm{CN}$ at $50{ }^{\circ} \mathrm{C}$ for $48 \mathrm{~h}$, gave a 10:90 mixture of $\mathbf{2 b}$ and $\mathbf{3 b}$.

(15) Spectral data for 6: ${ }^{1} \mathrm{H}$ NMR (DMSO- $\left.d_{6}, 400 \mathrm{MHz}\right) \delta 2.41(\mathrm{~s}, 3 \mathrm{H}), 3.29(\mathrm{~s}, 6 \mathrm{H}), 7.16(\mathrm{~d}, J=7.4,2 \mathrm{H}), 7.50(\mathrm{~d}, J=7.9$, 2H), 7.54-7.59 (m, 3H), 7.60-7.66 (m, 1H), $7.75(\mathrm{~d}, J=13.8,1 \mathrm{H}), 7.83(\mathrm{~d}, J=7.9,2 \mathrm{H}), 8.15(\mathrm{~d}, J=13.8,1 \mathrm{H}), 8.54(\mathrm{~d}, J=$ 7.5, 2H); ${ }^{13} \mathrm{C}$ NMR (DMSO- $\left.d_{6}, 100.6 \mathrm{MHz}\right) \delta 21.1,40.6,108.1,119.1,119.9,122.4,127.3,130.2,130.9,131.5,134.9,137.3$, 139.4, 140.9, 144.8, 145.3, 156.7, 167.8; HRMS (ESI+) $m / z$ calcd for $\mathrm{C}_{16} \mathrm{H}_{19} \mathrm{~N}_{2} \mathrm{O}_{2} \mathrm{~S}^{+}[\mathrm{M}]^{+}$303.1162, found: 303.1165 .

(16) Tertiary amines and the DMAP/tosylacetylene adducts are not basic enough to significantly deprotonate lactam CONH groups, so the conjugate addition reactions do not progress. When the lactam anions are generated with strong bases and tosylacetylene is added, proton exchanges occur to give the starting lactams — no reaction either — and tosylacetylide, Ts$\mathrm{C} \equiv \mathrm{C}^{-}$, which polymerizes (also see Ref. 9).

(17) We carried out one experiment of this type. We treated the sodium salt of butyrolactam (1j) with 6 (EDMAP ${ }^{+} \mathrm{CH}=\mathrm{CHTs}$ Sacc ${ }^{-}$, see Scheme 3) in $\mathrm{CH}_{3} \mathrm{CN}$ at $25^{\circ} \mathrm{C}$. The reaction was complete in less than 30 min. Compound $\mathbf{3 j}$ was isolated in $\geq 90 \%$ yield.

(18) The $N, S$-acetals (thiohemiaminals) were detected by ${ }^{1} \mathrm{H}$ NMR of the crude reaction mixtures. Characteristic signals (for the thiohemiaminal derived from $\mathbf{3 b}$ and dodecanethiol, $\mathrm{CDCl}_{3}, 400 \mathrm{MHz}$ ): $\delta 3.56$ (dd, $J=14.9, J=2.6,1 \mathrm{H}$ ), 4.67 (dd, $J=$ $14.9, J=11.7,1 \mathrm{H}), 5.71(\mathrm{dd}, J=11.7, J=2.6,1 \mathrm{H})$.

(19) Isolation and characterization of the aminal (addition product) from $\mathbf{4 j}$ and pyrrolidine as follows. Pyrrolidine $(67 \mu \mathrm{L}$, $0.81 \mathrm{mmol})$ was added to a solution of $\mathbf{4 j}(51 \mathrm{mg}, 0.20 \mathrm{mmol})$ in $\mathrm{CH}_{3} \mathrm{CN}(2 \mathrm{~mL})$. After stirring for $4.5 \mathrm{~h}$ at $\mathrm{rt}$, TLC indicated that the starting material had disappeared to give a less polar product. The solvent was removed under reduced pressure and the residue was purified by flash column chromatography on silica gel $\left(\mathrm{CH}_{2} \mathrm{Cl}_{2} / \mathrm{MeOH} 99: 1\right)$ to give the corresponding aminal, 7 (61 mg, 0.19 mmol, 92\%): oil; $R_{f}=0.20\left(\mathrm{CH}_{2} \mathrm{Cl}_{2} / \mathrm{MeOH} 99: 1\right) ;{ }^{1} \mathrm{H}$ NMR $\left(\mathrm{CDCl}_{3}, 400 \mathrm{MHz}\right) \delta 1.59-1.71(\mathrm{~m}, 4 \mathrm{H}), 1.71-1.81$ (m, 1H), 1.82-1.92 (m, 1H), 2.19-2.29 (m, 2H), 2.39-2.46 (m, 2H), 2.48-2.54 (m, 2H), 3.27-3.36 (m, 2H), 3.48 (dd, $J=14.8$, $J=3.3,1 \mathrm{H}), 3.66(\mathrm{dd}, J=14.8, J=9.9,1 \mathrm{H}), 4.89(\mathrm{dd}, J=9.9, J=3.3,1 \mathrm{H}), 7.52-7.58(\mathrm{~m}, 2 \mathrm{H}), 7.61-7.67$ (m, 1H), 7.89-7.93 (m, $2 \mathrm{H}) ;{ }^{13} \mathrm{C} \mathrm{NMR}\left(\mathrm{CDCl}_{3}, 100.6 \mathrm{MHz}\right) \delta 18.4,23.5,31.4,44.5,49.8,55.6,65.4,128.4,129.3,134.0,139.2,176.0$; HRMS (ESI+) $m / z$ calcd for $\mathrm{C}_{16} \mathrm{H}_{23} \mathrm{~N}_{2} \mathrm{O}_{3} \mathrm{~S}^{+}[\mathrm{M}+\mathrm{H}]^{+} 323.1424$, found: 323.1464 .

(20) (a) Review: Alonso, D. A.; Nájera, C. Org. React. 2008, 72, 367-656. Also see: (b) Cabianca, E.; Chéry, F.; Rollin, P.; Cossu, S.; de Lucchi, O. Synlett 2001, 1962-1964. (c) Cabianca, E.; Chéry, F.; Rollin, P.; Tatibouët, A.; de Lucchi, O. Tetrahedron Lett. 2002, 43, 585-587. (d) Chery, F.; Desroses, M.; Tatibouët, A.; de Lucchi, O.; Rollin, P. Tetrahedron 2003, 59, 4563-4572. (e) Chery, F.; Pillard, C.; Tatibouët, A.; de Lucchi, O.; Rollin, P. Tetrahedron 2006, 62, 5141-5151. 